\title{
Preparation and Evaluation of Biscuits Supplemented with some Natural Additives for Children and Adolescents Feeding
}

\author{
Saly, A. A. Saleh ${ }^{1}$; Mohamed, S. Abbas ${ }^{2}$; Mona, M. M. Doweidar ${ }^{\text {* }}$ and Amira, Sh. Soliman ${ }^{2}$ \\ ${ }^{1}$ Bread and Pastries Research Department, Food Technology Research Institute, Agriculture Research Center, Egypt \\ ${ }^{2}$ Natural Resources Department, Institute of African Research and Studies, Cairo University, Egypt
}

\section{Received: $12 / 5 / 2018$}

\begin{abstract}
To prepare and evaluate a healthy biscuit for reducing malnutrition diseases such as anemia and osteoporosis. Several models of two formulas were proposed by using five types of natural supplements; pumpkin (P), yellow corn germ $(\mathrm{G})$, white kidney bean $(\mathrm{Wb})$, rice bran $(\mathrm{R})$ and rosella flower $(\mathrm{K})$ to supplement wheat flour $72 \%$ extraction $(\mathrm{W})$. The results of the sensory evaluation showed that the biscuits supplemented from the following mixtures: PG $(80 \% \mathrm{~W}+10 \% \mathrm{P}+10 \% \mathrm{G}), \mathrm{PR}(80 \% \mathrm{~W}+10 \% \mathrm{P}+10 \% \mathrm{R}), \mathrm{PWb}(80 \% \mathrm{~W}+10 \% \mathrm{P}+10 \% \mathrm{~Wb}), \mathrm{WbG}(80 \% \mathrm{~W}+10 \% \mathrm{~Wb}+10 \% \mathrm{G})$ and $\mathrm{WbR}(80 \% \mathrm{~W}+10 \% \mathrm{~Wb}+10 \% \mathrm{R})$ as a duple mixes or $\mathrm{T} 3(75 \% \mathrm{~W}+10 \% \mathrm{R}+5 \% \mathrm{~Wb}+5 \% \mathrm{G}+3 \% \mathrm{P}+2 \% \mathrm{~K})$ as a multi mix had a very good degree of preference, so they were selected to be a chemically and physically evaluate and study the storage stability of the produced biscuits. The results of the chemical analysis indicated that all types of supplemented biscuit had high content of protein, fat, ash, crude fiber and total calories. They have a high mineral content (i.e., iron, zinc, calcium, manganese and magnesium), vitamins contents (i.e., A, E, K, B1, B $2, \mathrm{~B}_{3}, \mathrm{~B}_{6}$ and $\mathrm{B}_{9}$ ), total essential amino acids, biological value, protein efficiency ratio, total unsaturated fatty acids compared with the control. The color properties of the samples containing the pumpkin were improved. The spread factor and hardness of all types of supplemented biscuits was higher than those for the control. All types of supplemented biscuits were the highest in contribute of most of Recommended Dietary Allowances for a studied previous nutrient for children and adults. So it could be recommended to incorporate the investigated nutritional sources in bakery products to obtain healthy bakery products having high biological values, especially for resistance to anemia and osteoporosis due to the high content of the required nutrients.
\end{abstract}

Keywords: Biscuit, Natural additives, Nutritional value and Storage stability

\section{INTRODUCTION}

Malnutrition affects physical growth, morbidity, mortality, cognitive development, reproduction and physical work capacity, and it consequently impacts on human performance, health and survival. It is an underlying factor in many diseases for both children and adults and is particularly prevalent in developing countries (Pelletier and Frongillo, 2003; Branca et al., 2015 ; Alicke et al., 2017; Bates et al., 2017; Getahun et al., 2017; Suchdev, 2017). However, eating healthy foods is an important part of a healthy lifestyle and healthful nutritional practices need to be educated during childhood and early adolescence (RaghunathaRao et al., 2007; Wertich, 2013). Mineral deficiencies, especially of iron, calcium, and zinc, have a negative effect on human health and may lead to conditions such as iron deficiency anemia, rickets, osteoporosis, and diseases of the immune system (Yanagisawa, 2004; Pettifor et al., 2010; Al Rifai et al., 2016; Goulder et al., 2016; No, 2015; Hwalla et al., 2017; Pan et al., 2017; Wander et al., 2017).

School feeding is defined here as the provision of food to school children. There are as many types of programs as there are countries, but they can be classified into two main groups based on their modalities: (1) in-school feeding, where children are fed in school; and (2) take-home rations, where families are given food if their children attend school. In-school feeding can, in turn, be divided into two common categories: (1) programs that provide meals; and (2) programs that provide high-energy biscuits or snacks (Gelli and Daryanani, 2013; No, 2015).

*Corresponding author e-mail: mona.doweidar@live.com
Adolescence is the only time following infancy when the rate of physical growth actually increases. This sudden growth spurt is associated with hormonal, cognitive, and emotional changes that make adolescence an especially vulnerable period of life. First, (11-14 years of age) there is a greater demand for calories and nutrients due to the dramatic increase in physical growth and development over a relatively short period of time. Second (15-17 years of age), adolescence is a time of changing lifestyles and food habits that affect both nutrient needs and intake. Third (18-21 years of age), adolescent drive for individuation means more opportunity to assert food choices and expand or narrow healthy options (Stang and Story, 2005; McNeely and Blanchard, 2010; Sawyer et al., 2012; UNICEF, 2015).

Wheat (Triticum aestivum L.) bread is considered to be nutritionally poor and the supplementation of wheat flour with high protein- content flours is a powerful tool to improve the nutritional quality of bakery products (Sabanis and Tzia, 2009; ShahineFatma et al., 2013; Siddiq et al., 2013). Protein-enriched food from plant sources are rich in lysine, a limiting amino acid in wheat flour (Day, 2013; Chardigny and Walrand, 2016).

Dry beans occupy an important place in human nutrition, especially among the low - income groups of people in developing countries. The kidney bean (Phaseolus vulgaris L.) is one of the most important food legumes, consumed worldwide as pods of green beans or culinary processed seeds of dry beans. It is a good source of protein and rich in iron, manganese, phosphorous, copper, magnesium, vitamin E, and folate (B9). Furthermore, it has high content of soluble dietary

Volume 5 (1): 69-90 
fibers such gums, beta glucans, and pectin (Osorio-Diaz et al., 2003; Abdel- Gaber et al., 2006; Câmara et al., 2013; Brigide et al., 2014; El-Syiad and Hassan, 2014). Kidney beans have several health benefits. The bean consumption is associated with a reduced risk of cardiovascular disease, diabetes mellitus, obesity, and diseases of the digestive tract. These benefits are due to the presence of free cyclitol, soluble carbohydrate, protein, and antioxidants (Ribeiro et al., 2011; Singh et al., 2017). Furthermore, kidney beans have the availability of minerals like zinc and calcium and some antioxidants in higher quantities than soybeans, peanuts, and other legumes (Trinidad et al., 2010; Ntatsi et al., 2018).

Roselle (Hibiscus sabdariffa L.) is a very important herbaceous crop can be consumed for improvement the health condition due to its excellent nutritional value (FAO, 1988; Ahmed and Abozed, 2015). It is a good source of vitamins, minerals, protein, anthocyanin, dietary fiber, ascorbic acid, hibiscus acid and bioactive compounds such as organic acids, phytosterols and polyphenols and has a good antioxidant properties (Abdel-Moemin, 2016; Arpita et $a l ., 2017)$. It has lots of medicinal as well as commercial importance. Medicinal uses include its uses as antioxidant, anti-cancerous, antihypertensive and antimicrobial. It can also be used for curing anemia, diuretic and good for healthy bone and teeth formation. Commercially it can be used for the production of natural food color (Abouarab-Azza et al., 2011; Mohamed et al., 2012; Arpita et al., 2017). Roselle is native from India to Malaysia, where it is commonly cultivated, and must have been carried at an early date to Africa (Da-Costa-Rocha et al., 2014). Roselle is now cultivated in many tropical and subtropical regions of the world (Khalid et al., 2012; Gebremedin and Asfaw, 2017). Calyces of Roselle contain nine times more vitamin C than citrus (Mgaya et al., 2014; Ogundele et al., 2016).

Pumpkin (Cucurbita moschata) is an important source of dietary fiber, vitamins, carotenoids, ascorbic acid, polysaccharides, mineral compounds $(\mathrm{K}, \mathrm{Ca}, \mathrm{Mg}$ and $\mathrm{Fe}$ ), starch, and pectin (Li, 2008; Kulaitiene et al., 2014). Beta-carotene in plants that have a pleasant yellow-orange color is a major source of vitamin A (Lee, 1983; DeCarvalho et al., 2012). Consumption of foods containing carotene helps prevent skin diseases, eye disorders and cancer (Bendich, 1989; Faustino et al., 2016). It also contains other substances beneficial to health such as phenolic phytochemicals (Kwon et al., 2007; Dhiman et al., 2009; Amin et al., 2018).

Maize (Zea mays) is an important staple food in many countries of the world. The maize germ, which accounts for $5-14 \%$ of the weight of a maize kernel, depending on variety and grain size, is high in protein content, dietary fiber and minerals (Barbieri and Casiraghi, 1983; Naves et al., 2011) and are balanced in most of the essential amino acids; (Gupta and Eggum, 1998; Naves et al., 2011).

Rice bran (Oryza sativa L.) is the outer covering of rice kernel and consists of pericarp, aleurone, subaluerone layer, seed coat, nucellus, part of the germ and small part of starchy endosperm (Salunkhe et al., 1992; Hargrove, 1994; Raghav et al., 2016). It is a byproduct of rice milling industry and constitutes around $10 \%$ of the total weight of rough rice. Rice bran is a rich source of vitamins, minerals, essential fatty acids, dietary fiber and other sterols. Antioxidant compounds such as polyphenols, carotenoids, vitamin-E, gamma oryzanol, and tocotrienol which helps in preventing the oxidative damage of body tissues and DNA (Ling et al., 2002; Law et al., 2017; Tan and Norhaizan, 2017). Rice bran protein is a good source of well-balanced amino acid (Rohrer and Siebenmorgen, 2004; Phongthai et al., 2017). Rice is the most common staple food which is consumed by half of the World's human population. It is the third highest agricultural commodity with the worldwide production of sugarcane and maize (FAOSTAT, 2012).

Biscuit is most popular bakery product worldwide, with high in carbohydrates, fat and calorie but low in fiber, vitamin, and mineral which make it unhealthy for daily use. Because of its acceptability in all age group, longer shelf life, better taste and its position as snacks it is considered as a good product for protein fortification and other nutritional improvement (Serrem et al., 2011; Saini et al., 2017; Kumar et al., 2018). Therefore, this study was a trial to develop a suitable high nutrition values product(biscuit) for feeding school children by using different highly nutritional value sources (i.e. Pumpkin, yellow corn germ, white kidney bean, rice bran and roselle flower). The resultant biscuit was organoleptically, chemically, physically and microbiologically evaluated.

\section{MATERIALS AND METHODS}

\section{Materials:}

The current study was performed at, Food Tech. Res. Institute. Bread and Pastries Technology Research laboratory, Agric. Res. Center, Giza, Egypt, during two successive seasons (2015 and 2016).

-Wheat flour $72 \%$ extraction rate (Triticum aestivum L.) was obtained from Elfagr-wadi el melouk co. for milling, Egypt.

-Pumpkin (Cucurbita moschata) was obtained from Horticultural Research Institute, Agricultural Research Center, Doki, Giza, Egypt.

-Yellow corn germ (Zea mays) was obtained from Almasria to Starch and Glucose - Company- Mostorod, Egypt.

-White kidney bean (Phaseolus vulgaris L.) was obtained from Alsuhagy for Food Industries, Elkanater Elkhairia, Egypt.

-Stabilization rice bran was obtained from the experimental farm of Rice Mechanization Center (RM), Sakha, Egypt.

-Roselle calyxes and floral bracts (Hibiscus sabdriffa L.) were obtained from Medical and Aromatic Plants Research Dep., Agricultural Researches Center, Giza, Egypt.

-Chemicals used in this study were purchased from El-Gomhoria and El Shark El Aost Companies, Egypt. 


\section{Methods:-}

\section{Preparation of Pumpkin Flour:}

Pumpkin fruits were washed and peeled, fibrous matter and seeds were removed and the flesh was cuts into small pieces. The pumpkin pieces were then cut into slices of 2-3 $\mathrm{mm}$ thickness sheared using a slicer and dried in a ventilated oven at $150^{\circ} \mathrm{C} / 20 \mathrm{~min}$ to inhibit the oxidative and pectin enzymes, increase the evaporated water and decrease the microbial load. The slices were dried in a ventilated oven at $60^{\circ} \mathrm{C}$ until complete dryness. The dried pumpkin slices were grounded by using a mixer (MIENTA super blender, Model BL -721). Then the flour was sieved to pass through a 300 mesh siever. The resultant sieved flour was then kept in an airtight container and stored in a chiller prior to use (See et al., 2007).

\section{Preparation of yellow corn germ flour:}

The yellow corn germ was grounded by using a mixer $\{$ (MIENTA super blender) (Model BL -721)\}. Then sieved using 100 mesh siever and the obtained flour was finally packaged in sealed polyethylene bags due to the hygroscopic nature of the flour until used for blending and analysis.

\section{Preparation of Kidney bean flour:}

The kidney bean flour was prepared according to the method described by Giami and Bekebain (1992). One kilogram of kidney bean seeds which was free from dirty and other foreign materials such as stones, sticks. Seeds were ground by using mixer (MIENTA super blender, Model BL -721) and dried in the cabinet dryer $\left(120^{\circ} \mathrm{C} / 90 \mathrm{~min}\right)$. During drying, the ground seeds were stirred at intervals of 30 minutes to ensure uniform drying. The ground seeds were sieved to pass through a 300 mesh sieve. The milled seeds kidney bean flour, placed in an aluminum paper. The obtained flour was finally packaged in sealed polyethylene bags due to the hygroscopic nature of the flour until used for blending and analysis.
Preparation of heat stabilization rice bran Flour:

Heat Stabilization Rice bran (HRB) was sieved to pass through a 300 mesh sieve. And the fine rice bran powder was used in further experiments. The obtained flour was finally packaged in sealed polyethylene bags due to the hygroscopic nature of the flour until used for blending and analysis.

\section{Preparation of Roselle powder (Kujurat):}

Kerkrade calyx and floral bracts were prepared according to the method described by Cid-Ortega and Guerrero (2014) through ground by using a mixer (MIENTA super blender)(Model BL -721). The milled calyxes and floral bracts, were sieved to pass through a 300 mesh sieve, and finally packaged in sealed polyethylene bags due to the hygroscopic nature of the flour until used for blending and analysis.

\section{Preparation of biscuits:}

The biscuits were prepared in the lab of Bread and Pastries Research Dept., Food Technology Institute. Agric. Research Center. Ingredients used to make biscuits were given in Table (1). Biscuits were made according to the method described by Wade (1988) with some modification.

Table (1): The formula used for preparing sweet biscuits

\begin{tabular}{ll}
\hline Ingredients & Amount \\
\hline Wheat flour (72\% ex.) (g) & 100 \\
Egg $(\mathrm{g})$ & 24 \\
Sugar $(\mathrm{g})$ & 30 \\
Butter $(\mathrm{g})$ & 22 \\
Baking powder $(\mathrm{g})$ & 1.5 \\
Vanillin $(\mathrm{g})$ & 1 \\
\hline
\end{tabular}

\section{Treatments:}

Pretest experiment has been carried out to determine the best mix ratio of suggested raw materials which were chosen for this study as shown in the following Table (2).

Table (2): The suggested blends used for preparing sweet biscuits

\begin{tabular}{|c|c|c|c|}
\hline \multicolumn{2}{|l|}{ Treat. } & Blends composition & \multirow[t]{2}{*}{ G3* } \\
\hline Control & & Wheat flour $72 \%$ extraction rate (soft) & \\
\hline \multirow{10}{*}{ Duple mixes } & 1 & $80 \%$ wheat flour $+14 \%$ corn germ $+6 \%$ kujurat powder & GK \\
\hline & 2 & $80 \%$ wheat flour $+10 \%$ corn germ $+10 \%$ rice bran flour & GR \\
\hline & 3 & $80 \%$ wheat flour $+10 \%$ pumpkin pulp powder $+10 \%$ corn germ & PG \\
\hline & 4 & $80 \%$ wheat flour $+14 \%$ pumpkin pulp powder $+6 \%$ kujurat powder & PK \\
\hline & 5 & $80 \%$ wheat flour $+10 \%$ pumpkin pulp powder $+10 \%$ rice bran flour & PR \\
\hline & 6 & $80 \%$ wheat flour $+10 \%$ pumpkin pulp powder $+10 \%$ white kidney bean powder & $\mathrm{PWb}$ \\
\hline & 7 & $80 \%$ wheat flour $+14 \%$ rice bran flour $+6 \%$ kujurat powder & RK \\
\hline & 8 & $80 \%$ wheat flour $+10 \%$ white kidney bean powder $+10 \%$ corn germ & $\mathrm{WbG}$ \\
\hline & 9 & $80 \%$ wheat flour $+14 \%$ white kidney bean powder $+6 \%$ kujurat powder & $\mathrm{WbK}$ \\
\hline & 10 & $80 \%$ wheat flour $+10 \%$ white kidney bean powder $+10 \%$ rice bran flour & $\mathrm{WbR}$ \\
\hline \multirow{4}{*}{ Multi mixes } & 11 & $\begin{array}{l}75 \% \text { wheat flour }+5 \% \text { white kidney bean powder }+5 \% \text { corn germ }+5 \% \text { rice bran } \\
+5 \% \text { kujurat powder }+5 \% \text { pumpkin pulp powder }\end{array}$ & T1 \\
\hline & 12 & $\begin{array}{l}75 \% \text { wheat flour }+10 \% \text { white kidney bean powder }+5 \% \text { corn germ }+5 \% \text { rice bran } \\
\text { flour }+3 \% \text { pumpkin pulp powder }+2 \% \text { kujurat powder }\end{array}$ & $\mathrm{T} 2$ \\
\hline & 13 & $\begin{array}{l}75 \% \text { wheat flour }+10 \% \text { rice bran flour }+5 \% \text { white kidney bean powder }+5 \% \text { corn } \\
\text { germ }+3 \% \text { pumpkin pulp powder }+2 \% \text { kujurat powder })\end{array}$ & T3 \\
\hline & 14 & $\begin{array}{l}75 \% \text { wheat flour }+10 \% \text { corn germ }+5 \% \text { white kidney bean powder }+5 \% \text { rice bran } \\
\text { flour }+3 \% \text { pumpkin pulp powder }+2 \% \text { kujurat powder ) }\end{array}$ & T4 \\
\hline
\end{tabular}




\section{Preparation of sweet biscuits in the laboratory:}

For making biscuit: sugar and butter were creamed by using a mixing machine for 1 min. Eggs were beaten by whip and vanilla was added to the beaten eggs. Sugar- butter creamed was added to eggvanilla mixture and well beaten at low speed for $5 \mathrm{~min}$., dry ingredients (wheat flour or its blends and baking powder) were stirred together and added to the mixture gradually followed by beaten continuously until the blend became smooth, and the resulted dough was left to rest for $15 \mathrm{~min}$. The dough was rolled in a cookie sheet using a guide roll. The dough was cut in circles (5 $\mathrm{cm}$ diameter and $0.3 \mathrm{~cm}$ thick), and the transferred to greased plate, then the baking process was carried out in an electrically heater oven at $170^{\circ} \mathrm{C}$ for $12-15 \mathrm{~min}$. After baking, biscuits were allowed to cool at room temperature for $1 \mathrm{hr}$ before sensory evaluation (AACC, 2010).

Sensory characteristics estimation of experimental baked sweet biscuits:

A preliminary study was carried out for determination of the sensorial acceptable level of the mixed for investigated raw materials. The sensory characteristics of biscuits were evaluated according to the method of Manohar and Rao (1997) and were carried out by a panel of ten experienced judges from the staff of the Food Technol. Res. Institute, Agric. Res. Center, Giza, Egypt. Assigning scores for various quality attributes such as: color (20), texture (20), taste (20), crust appearance (20), odor (20), and overall acceptability (100) (San José et al., 2018).

\section{Packaging and Storage of produced biscuits:}

After identification of the best sensorial acceptable mixed level of the investigated raw material, the best treatment of biscuit was prepared as mentioned previously. After baking, biscuits were allowed to cool at the room temperature for $1 \mathrm{hr}$ then packaging as following: -Six pieces of biscuits (4-5g/each) were packed in transparence poly propylene packages $(20 / 20$ microns) in Food Engineering and Packaging Department Agricultural Research Center to evaluation the products quality during storage time for 180 days at room temperature $\left(20-25^{\circ} \mathrm{C}\right)$. Also, resultant biscuits were chemically and physically evaluation after baking.

\section{Chemical analysis:}

-Moisture, protein, ash, crude fat, crude fiber content, peroxide value and acid value were determined according to the method described in AOAC (2012).

-Available carbohydrates content of the sample was calculated by the difference as mentioned by Fraser and Holumes (1959).

$\%$ Available carbohydrates (on dry basis) $=100-$ (\%Ash +\%Fat +\%Protein +\%Fiber).

-The approximate energy of biscuits was calculated according to the (FAO/WHO, 1974) as follows:-

Total energy (K.cal/100g) = 4(\%carbohydrate $+\%$ protein) +9 (\% fat)

- Minerals content, i.e., Fe, $\mathrm{Zn}, \mathrm{Ca}, \mathrm{Mn}$ and $\mathrm{Mg}$ were determined by Atomic Absorption Spectrophotometer (3300 Perkin-Elmer) as described in AOAC (2012).
- Vitamin content: vitamin A, E, D and K were determined according to the methods described by Plozza et al (2012). Vitamin B group (B1, B2, B3, B6, B9and B12) were determined according to the methods described by Batifoulier et al. (2005).

- Amino acids were determined according to the method described in AOAC (2012) by using highperformance Amino Acids Analyzer (Biochroom 30).

- Protein Efficiency Ratio (PER) was estimated using the equation reported by Alsmeyer et al (1974) as follows:-

\section{$P E R=0.684+0.456$ (leucine) -0.047 (proline)}

- Biological value (BV) was estimated using the equation suggested by Mitchel and Block (1946) as follows:-

$$
\text { B. } V=49.9+10.53 P E R
$$

- Fatty acids were determined according to the method described in IUPAC (2000).

- Water activity $\left(\mathrm{a}_{\mathrm{w}}\right)$ was measured at $25^{\circ} \mathrm{C}$ by using a Decagon A qualab Meter Series 3TE (Pullman, WA, USA). All samples were broken into small pieces immediately before water activity measurement.

\section{Physical properties:}

According to Manohar and Rao (1997), the diameter (D) and thickness (T) of five biscuits were measured in millimeter by placing them the edge to edge and by stacking one above the other, respectively. To obtain the average, measurements were carried out by rearranging and restocking. Spread ratio was calculated by dividing the diameter of the biscuit $(\mathrm{mm})$ by their thickness ( $\mathrm{mm}$ ). The weight of five biscuits was determined after cooling. The volume was measured by displacement of rape seed. Specific volume was calculated by dividing volume $\left(\mathrm{cm}^{3}\right)$ by biscuit weight (g). A spread factor was calculated by mathematically divided spread ratio of the sample on spread ratio of control.

$$
\begin{aligned}
& \text { Spread ratio }=\frac{\text { Dinmeter }}{\text { Thwness }} \\
& \text { Spread factor }=\frac{\text { Spread ratio of somple }}{\text { Spread ratio of control }}
\end{aligned}
$$

\section{Texture Profile Analysis.}

A texture analyzer (BROOKFIELD CT3 TEXTURE ANALYZER Operating Instructions Manual No. M08-372-C0113, Stable Micro Systems, USA) was used to measure the texture profile of sweet biscuits in terms of hardness $(\mathrm{N})$ of the samples. Test Type: Compression, Target $=5.0 \mathrm{~mm}$, Hold Time $=0 \mathrm{~s}$, Trigger Load: $5.00 \mathrm{~N}$ (Newton), Test Speed $=2.00 \mathrm{~mm} / \mathrm{s}$, Return Speed $=2 \mathrm{~mm} / \mathrm{s}$, of Cycles: 1.0 , Pretest Speed: 2 $\mathrm{mm} / \mathrm{s}$, Probe: TA-PFS-C, Fixture: TA-RT-KIT, Load Cell: $10000 \mathrm{~g}$. The experiments were conducted under ambient conditions.

\section{Color measurements of biscuits.}

External color of the products was measured according to the method outlined by Mc Gurie (1992) using a handheld Chromameter (Model CR-400, Konica 
Minolta, Japan). The apparatus provided $L^{*}$ (lightness with $L=100$ for lightness, and $L=$ zero for darkness), $a^{*}\left[(\right.$ chromaticity on green $(-)$ to red $(+)], b^{*}$ [(chromaticity on a blue $(-)$ to yellow $(+)], c^{*}$ (color saturation $), h^{\circ}\left[\right.$ (hue angle were $0^{\circ}=$ red to purple, $90^{\circ}=$ yellow, $180^{\circ}=$ bluish to green and $270^{\circ}=$ blue] scale .

\section{Microbiological analysis.}

Total bacterial, Yeast, and molds count were determined according to the procedure described by Harrigan and McCance (1978).

\section{Statistical analysis:}

The data were obtained from sensory evaluations, chemical composition and physical properties were performed in triplicate for each sample by the least significant difference value (LSD) at 0.05 level probability procedure to analyze using statistical software SAS (1985).

\section{RESULTS AND DISCUSSION}

The chemical composition of the used raw materials:

The chemical composition of raw materials under investigation were found in the Table (3). It could be noticed that wheat flour $(72 \%$ ex.) contained the highest value of available carbohydrate $(87.61 \%)$ whereas it showed the lowest values of crude fat, ash and crude fiber $(0.98,0.63$ and $0.59 \%$, respectively). Wet milling corn germ contained the highest values of crude fat, crude fiber and energy (53.79\%, 18.48\% and 591.27 $\mathrm{Kcal} / 100 \mathrm{~g}$, respectively). While White kidney bean contained the highest value of protein (25.69\%) followed byheat stabilizations rice bran (14.85\%). Roselle calxes contained the highest value of ash $(11.09 \%)$. These results were nearly with that found by Bala et al. (2015), Goma-maha (2012), EL-Nagar (2005), El-Syiad and Hassan, (2014), Raghav et al. (2016) and Khalil et al. (2012).

Table (3): Chemical composition (\%) and minerals content (mg/100g) of raw materials which used for the preparation of biscuit types (on dry weight bases)

\begin{tabular}{|c|c|c|c|c|c|c|}
\hline $\begin{array}{c}\text { Composition } \\
(\%)\end{array}$ & $\begin{array}{c}\text { Wheat flour } \\
\text { (72\% ex.) }\end{array}$ & $\begin{array}{c}\text { Pumpkin } \\
\text { Pulp }\end{array}$ & $\begin{array}{l}\text { Wet milling } \\
\text { corn germ }\end{array}$ & $\begin{array}{c}\text { White Kidney } \\
\text { bean }\end{array}$ & $\begin{array}{c}\text { Heat } \\
\text { stabilizations } \\
\text { rice bran }\end{array}$ & $\begin{array}{c}\text { Roselle } \\
\text { calxes }\end{array}$ \\
\hline Moisture & $\begin{array}{l}12.92^{\mathrm{a}} \\
\pm 0.09\end{array}$ & $\begin{array}{l}10.12^{\mathrm{c}} \\
\pm 0.06\end{array}$ & $\begin{array}{l}2.10^{\mathrm{e}} \\
\pm 0.34\end{array}$ & $\begin{array}{l}2.01^{\mathrm{e}} \\
\pm 0.12\end{array}$ & $\begin{array}{l}6.93^{\mathrm{d}} \\
\pm 0.02\end{array}$ & $\begin{array}{l}11.35^{\mathrm{b}} \\
\pm 0.01\end{array}$ \\
\hline Protein & $\begin{array}{l}10.19^{\mathrm{d}} \\
\pm 0.16\end{array}$ & $\begin{array}{l}7.18^{\mathrm{e}} \\
\pm 0.80\end{array}$ & $\begin{array}{l}11.97^{\mathrm{c}} \\
\pm 0.21\end{array}$ & $\begin{array}{l}25.69^{\mathrm{a}} \\
\pm 0.09\end{array}$ & $\begin{array}{l}14.85^{\mathrm{b}} \\
\pm 0.09\end{array}$ & $\begin{array}{l}10.65^{\mathrm{d}} \\
\pm 0.13\end{array}$ \\
\hline Crude fat & $\begin{array}{c}0.98^{f} \\
\pm 0.15\end{array}$ & $\begin{array}{l}2.18^{\mathrm{d}} \\
\pm 0.12\end{array}$ & $\begin{array}{l}53.79^{\mathrm{a}} \\
\pm 0.22\end{array}$ & $\begin{array}{l}6.81^{\mathrm{c}} \\
\pm 0.05\end{array}$ & $\begin{array}{l}16.79^{\mathrm{b}} \\
\pm 0.06\end{array}$ & $\begin{array}{l}1.73^{\mathrm{e}} \\
\pm 0.20\end{array}$ \\
\hline Ash & $\begin{array}{l}0.63^{\mathrm{e}} \\
\pm 0.08\end{array}$ & $\begin{array}{l}7.20^{\mathrm{b}} \\
\pm 0.03\end{array}$ & $\begin{array}{l}0.94^{\mathrm{e}} \\
\pm 0.01\end{array}$ & $\begin{array}{l}3.21^{\mathrm{d}} \\
\pm 0.40\end{array}$ & $\begin{array}{l}6.04^{\mathrm{c}} \\
\pm 0.26\end{array}$ & $\begin{array}{l}11.09^{\mathrm{a}} \\
\pm 0.01\end{array}$ \\
\hline Crude fiber & $\begin{array}{l}0.59^{\mathrm{f}} \\
\pm 0.01\end{array}$ & $\begin{array}{l}8.55^{\mathrm{d}} \\
\pm 0.21\end{array}$ & $\begin{array}{l}18.48^{\mathrm{a}} \\
\pm 0.50\end{array}$ & $\begin{array}{l}3.39^{\mathrm{e}} \\
\pm 0.06\end{array}$ & $\begin{array}{l}9.34^{\mathrm{c}} \\
\pm 0.23\end{array}$ & $\begin{array}{l}14.97^{\mathrm{b}} \\
\pm 0.47\end{array}$ \\
\hline $\begin{array}{l}\text { Available } \\
\text { carbohydrate }\end{array}$ & $\begin{array}{l}87.61^{\mathrm{a}} \\
\pm 0.10\end{array}$ & $\begin{array}{l}74.89^{\mathrm{b}} \\
\pm 0.92\end{array}$ & $\begin{array}{l}14.82^{\mathrm{e}} \\
\pm 0.94\end{array}$ & $\begin{array}{l}60.90^{\mathrm{c}} \\
\pm 0.60\end{array}$ & $\begin{array}{l}52.98^{\mathrm{d}} \\
\pm 0.18\end{array}$ & $\begin{array}{l}61.56^{\mathrm{c}} \\
\pm 0.55\end{array}$ \\
\hline Energy & $400.02^{\mathrm{d}}$ & $347.90^{\mathrm{e}}$ & $591.27^{\mathrm{a}}$ & $407.65^{\mathrm{c}}$ & $422.43^{b}$ & $304.41^{\mathrm{f}}$ \\
\hline K.cal/100g & \pm 1.07 & \pm 1.54 & \pm 0.94 & \pm 1.57 & \pm 0.16 & \pm 0.93 \\
\hline \multicolumn{7}{|c|}{ Mineral mg/100g } \\
\hline $\mathbf{F e}$ & $\begin{array}{l}1.81^{\mathrm{d}} \\
\pm 0.01\end{array}$ & $\begin{array}{c}5.63^{\mathrm{c}} \\
\pm 0.135\end{array}$ & $\begin{array}{l}4.42^{\mathrm{cd}} \\
\pm 0.14\end{array}$ & $\begin{array}{l}6.61^{\mathrm{c}} \\
\pm 0.05\end{array}$ & $\begin{array}{l}28.20^{\mathrm{a}} \\
\pm 1.82\end{array}$ & $\begin{array}{l}13.70^{b} \\
\pm 0.50\end{array}$ \\
\hline Zn & $\begin{array}{l}1.15^{\mathrm{d}} \\
\pm 0.04\end{array}$ & $\begin{array}{l}4.89^{\mathrm{bc}} \\
\pm 0.26\end{array}$ & $\begin{array}{l}11.14^{\mathrm{a}} \\
\pm 0.59\end{array}$ & $\begin{array}{l}5.47^{\mathrm{b}} \\
\pm 2.08\end{array}$ & $\begin{array}{l}5.61^{\mathrm{b}} \\
\pm 0.83\end{array}$ & $\begin{array}{l}3.33^{\mathrm{c}} \\
\pm 0.01\end{array}$ \\
\hline Ca & $\begin{array}{l}20.67^{\mathrm{f}} \\
\pm 1.15\end{array}$ & $\begin{array}{l}91.71^{\mathrm{c}} \\
\pm 0.55\end{array}$ & $\begin{array}{l}22.72^{\text {ef }} \\
\pm 0.31\end{array}$ & $\begin{array}{l}302.94^{\mathrm{a}} \\
\pm 12.60\end{array}$ & $\begin{array}{l}41.88^{\mathrm{d}} \\
\pm 4.03\end{array}$ & $\begin{array}{c}153.59^{\mathrm{b}} \\
\pm 5.92\end{array}$ \\
\hline Mn & $\begin{array}{l}0.65^{\text {cd }} \\
\pm 0.08\end{array}$ & $\begin{array}{l}0.26^{\mathrm{e}} \\
\pm 0.01\end{array}$ & $\begin{array}{l}0.42^{\mathrm{de}} \\
\pm 0.04\end{array}$ & $\begin{array}{l}0.75^{\mathrm{c}} \\
\pm 0.02\end{array}$ & $\begin{array}{l}5.10^{\mathrm{a}} \\
\pm 0.08\end{array}$ & $\begin{array}{l}4.09^{\mathrm{b}} \\
\pm 0.31\end{array}$ \\
\hline Mg & $\begin{array}{l}18.61^{\mathrm{e}} \\
\pm 0.08\end{array}$ & $\begin{array}{c}59.30^{\mathrm{d}} \\
\pm 1.10\end{array}$ & $\begin{array}{l}21.30^{\mathrm{e}} \\
\pm 4.20\end{array}$ & $\begin{array}{l}66.53^{\mathrm{c}} \\
\pm 4.80\end{array}$ & $\begin{array}{l}75.70^{\mathrm{b}} \\
\pm 2.50\end{array}$ & $\begin{array}{l}83.33^{\mathrm{a}} \\
\pm 0.45\end{array}$ \\
\hline
\end{tabular}

Values are mean \pm SD.

Each value with the same row followed by the same letters is not significantly different at level of 0.05 .

\section{Minerals content of the used raw material:}

Minerals content of raw materials constitute a very important food mixtures calcium, iron, magnesium and zinc are the most important for physiological requirements of children. For example calcium is combined as the salts give hardness to bones and teeth, iron is required for an expanding blood volume and increasing amounts of hemoglobin in grown children, magnesium is essential for all living cell, it is a catalyst in numerous metabolic reaction and zinc as an integral part of least 20 enzymes that belong to a large group known as metabloenzymes (Beard, 2001; Hotez and Brown, 2004 and Soetan et al., 2010). 
The data presented in Table (3), demonstrated that wet milling corn germ had the highest value of $\mathrm{Zn}$ $(11.14 \mathrm{mg} / 100 \mathrm{~g})$. White kidney bean had the highest value of Ca $(302.94 \mathrm{mg} / 100 \mathrm{~g})$. Heat Stabilizations rice bran had the highest values for Fe $(28.20 \mathrm{mg} / 100 \mathrm{~g})$ and $\mathrm{Mn}(5.10 \mathrm{mg} / 100 \mathrm{~g})$. Rosella calxes had the highest value of $\mathrm{Mg}(83.33 \mathrm{mg} / 100 \mathrm{~g})$. While soft wheat flour $(72 \%$ extraction) had the lowest value in these previous minerals $(1.81,1.15,20.67,0.65$ and $18.61 \mathrm{mg} / 100$ gfor $\mathrm{Fe}, \mathrm{Zn}, \mathrm{Ca}, \mathrm{Mn}$ and $\mathrm{Mg}$, respectively). These results were nearly with that found by Ahmed and Abozed (2015) for Rosella calxes and Naves et al. (2011) for corn germ.

Also, from the present data, it is clearly noticed that combination of soft wheat flour ( $72 \%$ extraction) with raw materials under investigation as a flour supplemented caused an increase in minerals content in mixed flour.

\section{Sensory evaluation of preliminary blends of sweet} biscuits:

Sensory evaluation is considered as an important indicator of potential consumer preferences, In spite of its shortcomings, it will remain one of the most reliable quality assessment technique for food and food products in general and for bread and bakery products in particular (Stone, 2012). So that pretest experiment has been carried out to determine the best mixes ratios of suggested raw materials and selected for this study. Overall acceptability of produce sweet biscuits as a result of the effect of all sensory characteristics, evaluated as "90-100 degrees was very good" in comparison to "Less than 70 degrees was questionable". The sensory evaluation of double mixes from suggested raw materials, Table (4) showed that samples PG, PR, $\mathrm{PWb}, \mathrm{WbG}$ and $\mathrm{WbR}$ had a slight significant difference compared with control biscuit, and still had very good acceptable scores. With respect to produce sweet biscuits strengthening with formulated of mixes additives, Table (5) showed that sample T3 were not significantly differenced compared with control biscuit, and had a very good acceptable scores. So these previous levels which obtained very good acceptability could be selected for evaluation in this study. These results are in good agreement with those reported by Afify-Haiat (2012) and Shahine-Fatma et al. (2013).

Table (4): Sensory evaluation of biscuits supplemented with double of additives

\begin{tabular}{|c|c|c|c|c|c|c|c|}
\hline Biscuit's samples & $\begin{array}{c}\text { General } \\
\text { appearance } \\
(20)\end{array}$ & $\begin{array}{l}\text { Odor } \\
(20)\end{array}$ & $\begin{array}{l}\text { Taste } \\
(20\end{array}$ & $\begin{array}{l}\text { Crispy } \\
\text { (20) }\end{array}$ & $\begin{array}{l}\text { Color } \\
(20)\end{array}$ & $\begin{array}{l}\text { Total } \\
\text { score } \\
(100) \\
\end{array}$ & Acceptance \\
\hline $\begin{array}{l}100 \% \mathrm{~W} \\
\text { (Con.) }\end{array}$ & $\begin{array}{l}19.60^{\mathrm{a}} \\
\pm 0.70\end{array}$ & $\begin{array}{l}19.40^{\mathrm{a}} \\
\pm 0.70\end{array}$ & $\begin{array}{l}19.45^{\mathrm{a}} \\
\pm 0.69\end{array}$ & $\begin{array}{l}19.40^{\mathrm{a}} \\
\pm 0.52\end{array}$ & $\begin{array}{l}19.40^{\mathrm{a}} \\
\pm 0.82\end{array}$ & $\begin{array}{l}97.15^{\mathrm{a}} \\
\pm 3.04\end{array}$ & $\mathbf{V}$ \\
\hline $\begin{array}{l}80 \% W+14 \% G+6 \% K \\
(G K)\end{array}$ & $\begin{array}{l}17.40^{\mathrm{cd}} \\
\pm 1.08\end{array}$ & $\begin{array}{l}16.50^{\text {ef }} \\
\pm 1.90\end{array}$ & $\begin{array}{l}16.60^{\mathrm{c}} \\
\pm 1.78\end{array}$ & $\begin{array}{l}16.45^{\mathrm{c}} \\
\pm 2.06\end{array}$ & $\begin{array}{l}17.25^{\mathrm{c}} \\
\pm 1.32\end{array}$ & $\begin{array}{l}84.20^{\mathrm{d}} \\
\pm 6.05\end{array}$ & $\mathbf{G}$ \\
\hline $\begin{array}{l}80 \% W+10 \% G+10 \% R \\
(G R)\end{array}$ & $\begin{array}{l}17.60^{\mathrm{cd}} \\
\pm 1.51\end{array}$ & $\begin{array}{l}17.20^{\text {edf }} \\
\pm 1.93\end{array}$ & $\begin{array}{l}17.00^{\mathrm{bc}} \\
\pm 2.06\end{array}$ & $\begin{array}{l}17.20^{\mathrm{bc}} \\
\pm 2.35\end{array}$ & $\begin{array}{l}17.90^{\mathrm{bc}} \\
\pm 1.73\end{array}$ & $\begin{array}{l}86.90 c^{\mathrm{d}} \\
\pm 8.37\end{array}$ & $\mathbf{G}$ \\
\hline $\begin{array}{l}80 \% W+10 \% P+10 \% G \\
(P G)\end{array}$ & $\begin{array}{l}19.30^{\mathrm{a}} \\
\pm 0.68\end{array}$ & $\begin{array}{l}18.90^{\mathrm{a}} \\
\pm 0.74\end{array}$ & $\begin{array}{l}17.75^{\mathrm{bc}} \\
\pm 1.28\end{array}$ & $\begin{array}{l}17.80^{\mathrm{b}} \\
\pm 1.49\end{array}$ & $\begin{array}{l}19.25^{\mathrm{a}} \\
\pm 0.64\end{array}$ & $\begin{array}{l}93.00^{\mathrm{ab}} \\
\pm 3.21\end{array}$ & $\mathbf{V}$ \\
\hline $\begin{array}{l}80 \% W+14 \% \mathrm{P}+6 \% \mathrm{~K} \\
(\mathrm{PK})\end{array}$ & $\begin{array}{l}18.00^{\mathrm{bcd}} \\
\pm 1.25\end{array}$ & $\begin{array}{l}17.60^{\text {bcde }} \\
\pm 1.08\end{array}$ & $\begin{array}{l}17.00^{\mathbf{b c}} \\
\pm 1.56\end{array}$ & $\begin{array}{l}17.35^{\text {bc }} \\
\pm 1.38\end{array}$ & $\begin{array}{l}17.50^{\mathrm{c}} \\
\pm 1.38\end{array}$ & $\begin{array}{l}87.45^{\mathrm{cd}} \\
\pm 4.43\end{array}$ & $\mathbf{G}$ \\
\hline $\begin{array}{l}80 \% W+10 \% P+10 \% R \\
(P R)\end{array}$ & $\begin{array}{l}18.90^{\mathrm{ab}} \\
\pm 0.88\end{array}$ & $\begin{array}{l}18.60^{\mathbf{a b}} \\
\pm 0.97\end{array}$ & $\begin{array}{l}17.40^{\mathrm{bc}} \\
\pm 1.17\end{array}$ & $\begin{array}{l}17.50^{\mathrm{bc}} \\
\pm 1.67\end{array}$ & $\begin{array}{l}18.90^{\mathrm{ab}} \\
\pm 0.99\end{array}$ & $\begin{array}{l}91.30^{\mathrm{bc}} \\
\pm 4.39\end{array}$ & $\mathbf{V}$ \\
\hline $\begin{array}{l}80 \% W+10 \% P+10 \% W b \\
(P W b)\end{array}$ & $\begin{array}{l}19.40^{\mathrm{a}} \\
\pm 0.52\end{array}$ & $\begin{array}{l}19.00^{\mathrm{a}} \\
\pm 0.67\end{array}$ & $\begin{array}{l}18.20^{\mathrm{ab}} \\
\pm 1.23\end{array}$ & $\begin{array}{l}18.05^{\mathrm{b}} \\
\pm 1.12\end{array}$ & $\begin{array}{l}19.25^{\mathrm{a}} \\
\pm 0.72\end{array}$ & $\begin{array}{l}93.90^{\mathrm{ab}} \\
\pm 2.86\end{array}$ & $\mathbf{V}$ \\
\hline $\begin{array}{l}80 \% W+14 \% R+6 \% K \\
(\mathrm{RK})\end{array}$ & $\begin{array}{l}17.10^{\mathrm{d}} \\
\pm 1.97\end{array}$ & $\begin{array}{l}16.10^{\mathbf{f}} \\
\pm 2.42\end{array}$ & $\begin{array}{l}16.90^{\mathrm{bc}} \\
\pm 2.18\end{array}$ & $\begin{array}{l}17.10^{\mathrm{bc}} \\
\pm 1.52\end{array}$ & $\begin{array}{l}17.20^{\mathrm{c}} \\
\pm 1.62\end{array}$ & $\begin{array}{l}84.40^{\mathrm{d}} \\
\pm 8.71\end{array}$ & $\mathbf{G}$ \\
\hline $\begin{array}{l}80 \% W+10 \% W b+10 \% G \\
(W b G)\end{array}$ & $\begin{array}{l}18.75^{\mathrm{ab}} \\
\pm 0.98\end{array}$ & $\begin{array}{c}18.50^{\mathrm{abc}} \\
\pm 1.27\end{array}$ & $\begin{array}{l}18.20^{\mathrm{ab}} \\
\pm 0.92\end{array}$ & $\begin{array}{l}18.05^{\mathrm{b}} \\
\pm 0.83\end{array}$ & $\begin{array}{l}19.05^{\mathrm{a}} \\
\pm 0.83\end{array}$ & $\begin{array}{l}92.55^{\mathrm{ab}} \\
\pm 3.98\end{array}$ & $\mathbf{V}$ \\
\hline $\begin{array}{l}80 \% W+14 \% W b+6 \% K \\
(W b K)\end{array}$ & $\begin{array}{l}17.40^{\mathbf{c d}} \\
\pm 1.58\end{array}$ & $\begin{array}{l}17.30^{\text {cdef }} \\
\pm 1.25\end{array}$ & $\begin{array}{l}17.35^{\mathrm{bc}} \\
\pm 1.92\end{array}$ & $\begin{array}{l}17.10^{\mathrm{bc}} \\
\pm 1.91\end{array}$ & $\begin{array}{l}17.10^{\mathrm{c}} \\
\pm 1.60\end{array}$ & $\begin{array}{l}86.25^{\mathrm{d}} \\
\pm 5.12\end{array}$ & $\mathbf{G}$ \\
\hline $\begin{array}{l}\mathbf{8 0} \% W+10 \% W b+10 \% R \\
(W b R)\end{array}$ & $\begin{array}{l}18.20^{\mathrm{bc}} \\
\pm 1.14\end{array}$ & $\begin{array}{l}18.20^{\mathrm{abcd}} \\
\pm 0.92\end{array}$ & $\begin{array}{l}18.00^{\mathrm{b}} \\
\pm 0.82\end{array}$ & $\begin{array}{l}18.40^{\mathrm{ab}} \\
\pm 0.70\end{array}$ & $\begin{array}{l}18.60^{\mathrm{ab}} \\
\pm 0.84\end{array}$ & $\begin{array}{l}91.40^{\mathrm{bc}} \\
\pm 3.27\end{array}$ & $\mathbf{V}$ \\
\hline
\end{tabular}

Values are mean \pm SD.

Each value with the same column followed by the same letters is not significantly different at level of $0.0590-100$ very good (V) 80-89 Good (G) 70-79 Satisfactory (S) Less than 70 questionable (Q)

$\mathrm{W}=$ wheat flour $\mathrm{P}=$ Pumpkin $\mathrm{G}=$ Yellow corn germ $\mathrm{R}=$ Stabilization rice bran $\mathrm{K}=$ kjurat (Rosall calxes)

$\mathrm{Wb}=$ White Kidney bean as according to the Table (2). 
Table (5): Sensory evaluation of biscuits supplemented with multi additives

\begin{tabular}{|c|c|c|c|c|c|c|c|}
\hline Biscuit's samples & $\begin{array}{c}\text { General } \\
\text { appearance } \\
(\mathbf{2 0})\end{array}$ & $\begin{array}{l}\text { Odor } \\
(20)\end{array}$ & $\begin{array}{c}\text { Taste } \\
(20\end{array}$ & $\begin{array}{c}\text { Crispy } \\
\text { (20) }\end{array}$ & $\begin{array}{c}\text { Color } \\
\text { (20) }\end{array}$ & $\begin{array}{l}\text { Total } \\
\text { score } \\
(\mathbf{1 0 0 )} \\
\end{array}$ & Acceptance \\
\hline Con $(100 \%$ W) & $\begin{array}{l}19.20^{\mathrm{a}} \\
\pm 0.92\end{array}$ & $\begin{array}{l}19.20^{\mathrm{a}} \\
\pm 0.92\end{array}$ & $\begin{array}{l}18.90^{\mathrm{a}} \\
\pm 1.45\end{array}$ & $\begin{array}{l}18.80^{\mathrm{a}} \\
\pm 1.45\end{array}$ & $\begin{array}{l}19.00^{\mathrm{a}} \\
\pm 1.33\end{array}$ & $\begin{array}{l}95.10^{\mathrm{a}} \\
\pm 5.80\end{array}$ & $\mathbf{V}$ \\
\hline $\begin{array}{l}\text { T1 } \\
(75 \% W+5 \% W b+5 \% G \\
+5 \% R+5 \% K+5 \% P)\end{array}$ & $\begin{array}{l}17.20^{\mathrm{c}} \\
\pm 1.03\end{array}$ & $\begin{array}{r}18.20^{\mathrm{a}} \\
\pm 1.398\end{array}$ & $\begin{array}{l}17.60^{b} \\
\pm 1.08\end{array}$ & $\begin{array}{l}17.90^{\mathrm{a}} \\
\pm 1.29\end{array}$ & $\begin{array}{l}16.60^{\mathrm{b}} \\
\pm 0.70\end{array}$ & $\begin{array}{l}87.50^{\mathrm{b}} \\
\pm 3.81\end{array}$ & G \\
\hline $\begin{array}{l}\text { T2 } \\
(75 \% W+10 \% W b+5 \% G \\
+5 \% R+3 \% P+2 \% K)\end{array}$ & $\begin{array}{c}17.50^{\text {bc }} \\
\pm 0.85\end{array}$ & $\begin{array}{l}18.30^{\mathrm{a}} \\
\pm 1.34\end{array}$ & $\begin{array}{l}17.9^{\mathrm{ab}} \\
1 \pm .52\end{array}$ & $\begin{array}{l}17.50^{\mathrm{a}} \\
\pm 2.07\end{array}$ & $\begin{array}{l}16.60^{\mathrm{b}} \\
\pm 1.07\end{array}$ & $\begin{array}{l}87.80^{\mathrm{b}} \\
\pm 5.94\end{array}$ & G \\
\hline $\begin{array}{l}\text { T3 } \\
(75 \% W+10 \% R+5 \% W b \\
+5 \% G+3 \% P+2 \% K)\end{array}$ & $\begin{array}{l}18.20^{\mathrm{b}} \\
\pm 0.79\end{array}$ & $\begin{array}{l}18.40^{\mathrm{a}} \\
\pm 1.43\end{array}$ & $\begin{array}{l}18.10^{\mathrm{ab}} \\
\pm 1.10\end{array}$ & $\begin{array}{l}18.30^{\mathrm{a}} \\
\pm 1.10\end{array}$ & $\begin{array}{l}17.40^{\mathrm{b}} \\
\pm 1.17\end{array}$ & $\begin{array}{l}90.40^{\mathrm{ab}} \\
\pm 4.74\end{array}$ & $\mathrm{~V}$ \\
\hline $\begin{array}{l}\text { T4 } \\
(75 \% W+10 \% G+5 \% W b \\
+5 \% R+3 \% p+2 \% K\end{array}$ & $\begin{array}{c}17.70^{\mathrm{bc}} \\
\pm 1.06\end{array}$ & $\begin{array}{l}18.10^{\mathrm{a}} \\
1 \pm .52\end{array}$ & $\begin{array}{c}17.75^{\mathrm{ab}} \\
\pm 1.88\end{array}$ & $\begin{array}{l}17.60^{\mathrm{a}} \\
\pm 1.78\end{array}$ & $\begin{array}{l}17.10^{\mathrm{b}} \\
\pm 1.20\end{array}$ & $\begin{array}{l}88.25^{\mathrm{b}} \\
\pm 6.63\end{array}$ & G \\
\hline
\end{tabular}

\section{Chemical composition of resultant biscuits:}

An adequate knowledge of the chemical composition of food is vital to the health, well-being and safety of the consumer (Jansen van Rijssen et al., 2013; Toomer, 2017).

The chemical changes in selected sweet biscuits as influenced by supplementation of different suggested raw material were studied and the obtained results are shown in the Table (6). The protein content ranged between $8.12 \%$ in the PG Sample and $8.98 \%$ for the PWb sample compared with $7.60 \%$ for the control. As to the fat content ranged between $15.03 \%$ in $\mathrm{PWb}$ sample and $17.96 \%$ for WbG sample compared with $13.63 \%$ for control. The determination of ash content reveals information relating to minerals. In the present study, there was no significant difference in ash content for supplemented samples, the values of ash content varied between $1.82 \%$ in sample $\mathrm{WbG}$ and $2.26 \%$ for PR sample compared with $1.06 \%$ for control. The crude fiber content of the different samples was found to vary between $0.30 \%$ in $\mathrm{T} 3$ sample and $1.88 \%$ for PG sample compared with $0.30 \%$ for control. Regarding the available carbohydrates content, it was observed that the values varied from $69.97 \%$ in $\mathrm{WbG}$ sample and $72.93 \%$ in PWb sample compared with $76.87 \%$ for control. The energy values varied from $464.51 \mathrm{Kcal} / 100 \mathrm{~g}$ in sample $\mathrm{PR}$ and $478.13 \mathrm{Kcal} / 100 \mathrm{~g}$ in T3sample compared with $460.55 \mathrm{Kcal} / 100 \mathrm{~g}$ for control. These results are due to the different nutritional values of raw materials used. These results are in agreement with the results given by Mishral and Chandra (2012), Afifi-Haiat (2012) and Abdel-Moemin (2016), Gomaa-Maha (2012) and Shahine-Fatma (2013).

\section{Minerals content of biscuit:}

Also, from the results presented in the Table (6), it could be demonstrated that $\mathrm{WbR}$ sample had the highest values of $\mathrm{Fe}, \mathrm{Mn}$ and $\mathrm{Mg}$ (3.31, 0.84 and 19.08 $\mathrm{mg} / 100 \mathrm{~g}$, respectively.). The highest value of $\mathrm{Zn}$ was observed in T3 sample $(1.51 \mathrm{mg} / 100 \mathrm{~g})$. While the highest value of $\mathrm{Ca}$ was obtained in sample PWb (31.08 $\mathrm{mg} / 100 \mathrm{gm})$. On the other hand control sample contained the lowest value for $\mathrm{Fe}, \mathrm{Zn}, \mathrm{Ca}, \mathrm{Mn}$ and $\mathrm{Mg}$ (1.50, 0.72, 0.37 and $11.56 \mathrm{mg} / 100 \mathrm{~g}$, respectively. These results are in a good agreement with those reported by EL-Nagar (2005), Gomaa-Maha (2012), Shahine-Fatma et al. (2013), Ahmed and Abozed (2015), and Younas et al. (2011).

\section{Vitamins content of biscuit:}

The data outlined in Table (7) showed that, all samples of supplemented biscuit had an increasing values of vitamins contents i.e., A, E, K, Thiamine (B1), Riboflavin (B2), Nicotinic acid (B3), Pyridoxin (B6) and Folic Acid (B9) compared with control (unsupplemented biscuit). Hence, supplemented biscuits are favorable than control (unsupplemented biscuit) because of their high content of important vitamins. These data are agreed with findings of Gomaa-Maha (2012) and Shahine-Fatma et al. (2013) and Raghav et al. (2016) and Anel et al. (2016).

\section{Amino acids content of supplemented biscuit:}

Protein quality is partly dependent upon its amino acid profile. The non-essential amino acids are those the body can synthesize and therefore non-essential in the diet. The essential amino acids, on the other hand are very important from the nutritional point of view since the body cannot make and should, therefore, be supplemented in the diet (Mohammed et al., 2016). The quality of the protein in the biscuits was investigated in terms of the essential amino acid content and PER and $\mathrm{BV}$, which is a method of evaluating the protein quality. The data in Table (8) showed that, all samples of supplemented biscuits had the highest quantity of 
Leucine, Threonine, and Valine and total essential amino acids (total EAA) and other amino acids such as arginine and aspartic, compared to those in control biscuits. However, proline and total non-essential amino acids (total NEAA) were higher in control biscuits than in supplemented biscuits.
The protein efficiency ratio (PER) and biological value $(\mathrm{BV})$ of all supplemented biscuits were higher than that for control biscuits. And WbR sample had the highest value of total EAA, PER, and BV than control biscuits and other produced supplemented biscuits.

Table (6): Chemical composition (\%) and minerals content (mg/100g) of selected biscuits (on dry weight bases)

\begin{tabular}{|c|c|c|c|c|c|c|c|}
\hline \multirow{2}{*}{$\begin{array}{l}\text { Composition } \\
(\%)\end{array}$} & \multicolumn{7}{|c|}{ Biscuit's samples } \\
\hline & Con & $\mathbf{P W b}$ & PG & PR & WbG & WbR & T3 \\
\hline Protein & $\begin{array}{l}7.60^{\mathrm{b}} \\
\pm 0.79\end{array}$ & $\begin{array}{l}8.98^{\mathrm{a}} \\
\pm 0.14\end{array}$ & $\begin{array}{l}8.12^{\mathrm{ab}} \\
\pm 0.21\end{array}$ & $\begin{array}{l}8.47^{\mathrm{ab}} \\
\pm 0.10\end{array}$ & $\begin{array}{l}8.67^{\mathrm{a}} \\
\pm 0.58\end{array}$ & $\begin{array}{l}8.85^{\mathrm{a}} \\
\pm 0.89\end{array}$ & $\begin{array}{c}8.78^{\mathrm{a}} \\
\pm 0.46\end{array}$ \\
\hline Fat & $\begin{array}{l}13.63^{\mathrm{d}} \\
\pm 1.29\end{array}$ & $\begin{array}{l}15.03^{\mathrm{c}} \\
\pm 0.18\end{array}$ & $\begin{array}{c}17.05^{\mathrm{ab}} \\
\pm 1.33\end{array}$ & $\begin{array}{l}15.75^{\mathrm{bc}} \\
\pm 0.15\end{array}$ & $\begin{array}{l}17.96^{\mathrm{a}} \\
\pm 0.61\end{array}$ & $\begin{array}{c}15.86^{\mathrm{bc}} \\
\pm 0.24\end{array}$ & $\begin{array}{l}17.64^{\mathrm{a}} \\
\pm 0.07\end{array}$ \\
\hline Ash & $\begin{array}{c}1.06^{\mathrm{b}} \\
\pm 0.50\end{array}$ & $\begin{array}{l}2.11^{\mathrm{a}} \\
\pm 0.53\end{array}$ & $\begin{array}{r}1.95^{\mathrm{a}} \\
\pm 0.53\end{array}$ & $\begin{array}{c}2.26^{\mathrm{a}} \\
\pm 0.56\end{array}$ & $\begin{array}{l}1.82^{\mathrm{ab}} \\
\pm 0.41\end{array}$ & $\begin{array}{l}2.08^{\mathrm{a}} \\
\pm 0.49\end{array}$ & $\begin{array}{l}2.22^{\mathrm{a}} \\
\pm 0.53\end{array}$ \\
\hline Crude fiber & $\begin{array}{c}0.30^{\mathrm{e}} \\
\pm 0.03\end{array}$ & $\begin{array}{c}0.95^{\mathrm{d}} \\
\pm 0.07\end{array}$ & $\begin{array}{c}1.88^{\mathrm{a}} \\
\pm 0.15\end{array}$ & $\begin{array}{c}1.30^{\mathrm{c}} \\
\pm 0.10\end{array}$ & $\begin{array}{c}1.58^{\mathrm{b}} \\
\pm 0.13\end{array}$ & $\begin{array}{c}1.00^{\mathrm{d}} \\
\pm 0.09\end{array}$ & $\begin{array}{c}0.30^{\mathrm{e}} \\
\pm 0.03\end{array}$ \\
\hline Available & $76.87^{\mathrm{a}}$ & $72.93^{\mathrm{b}}$ & $71.00^{\mathrm{bc}}$ & $72.22^{b c}$ & $69.97^{\mathrm{c}}$ & $72.21^{\mathrm{bc}}$ & $71.07^{\mathrm{bc}}$ \\
\hline Carbohydrate & \pm 2.59 & \pm 0.64 & \pm 2.21 & \pm 0.89 & \pm 1.73 & \pm 1.71 & \pm 1.08 \\
\hline Energy & $460.55^{\mathrm{d}}$ & $473.85^{\mathrm{cd}}$ & $469.93^{\mathrm{b}}$ & $464.51^{\mathrm{cd}}$ & $476.20^{\mathrm{a}}$ & $466.98^{\mathrm{bc}}$ & $478.13^{\mathrm{a}}$ \\
\hline Kcal/100g & \pm 4.35 & \pm 1.51 & \pm 3.93 & \pm 1.88 & \pm 0.89 & \pm 1.10 & \pm 1.88 \\
\hline \multicolumn{8}{|c|}{ Minerals content (mg/100g) } \\
\hline & $1.50^{\mathrm{c}}$ & $2.30^{\mathrm{b}}$ & $2.21^{\mathrm{b}}$ & $3.17^{\mathrm{a}}$ & $2.25^{\mathrm{b}}$ & $3.31^{\mathrm{a}}$ & $3.01^{\mathrm{a}}$ \\
\hline $\mathbf{F e}$ & \pm 0.48 & \pm 0.12 & \pm 0.06 & \pm 0.36 & \pm 0.34 & \pm 0.31 & \pm 0.58 \\
\hline & $0.72^{\mathrm{e}}$ & $1.16^{\mathrm{d}}$ & $1.45^{\mathrm{ab}}$ & 1. $27^{\mathrm{cd}}$ & $1.31^{\mathrm{bc}}$ & $1.39^{\mathrm{abc}}$ & $1.51^{\mathrm{a}}$ \\
\hline Zn & \pm 0.09 & \pm 0.14 & \pm 0.12 & \pm 0.03 & \pm 0.00 & \pm 0.02 & \pm 0.04 \\
\hline & $13.22^{\mathrm{b}}$ & $31.08^{\mathrm{a}}$ & $18.30^{\mathrm{b}}$ & $19.15^{\mathrm{b}}$ & $23.28^{\mathrm{ab}}$ & $23.85^{\mathrm{ab}}$ & $23.91^{\mathrm{ab}}$ \\
\hline Ca & \pm 0.85 & \pm 10.47 & \pm 7.29 & \pm 7.78 & \pm 13.79 & \pm 14.56 & \pm 9.66 \\
\hline Mn & $0.37^{\mathrm{cd}}$ & $0.50^{\mathrm{b}}$ & $0.28^{\mathrm{d}}$ & $0.57^{\mathrm{b}}$ & $0.49^{b c}$ & $0.84^{\mathrm{a}}$ & $0.82^{\mathrm{a}}$ \\
\hline Min & \pm 0.01 & \pm 0.01 & \pm 0.01 & \pm 0.19 & \pm 0.02 & \pm 0.04 & \pm 0.02 \\
\hline & $11.56^{\mathrm{c}}$ & $17.80^{\mathrm{a}}$ & $14.37^{\mathrm{b}}$ & \pm 0.65 & $15.41^{b}$ & $19.08^{\mathrm{a}}$ & $17.77^{\mathrm{a}}$ \\
\hline Mg & \pm 1.35 & \pm 0.50 & \pm 1.15 & $17.87^{*} \pm 0.65$ & \pm 0.30 & \pm 0.10 & \pm 0.95 \\
\hline
\end{tabular}

Values are mean \pm SD.

Each value with the same row is followed by the same letters is not significantly different at the level of 0.05 .

Table (7): Vitamins contain of biscuits made from mixed blends ( $\%$ on dry weight basis).

\begin{tabular}{|c|c|c|c|c|c|c|c|}
\hline \multirow{2}{*}{ Vitamins } & \multicolumn{7}{|c|}{ Biscuit's samples } \\
\hline & Con. & PWb & PG & PR & WbG & WbR & T3 \\
\hline $\begin{array}{l}\text { V.A } \\
(\mu g / 100 g)\end{array}$ & 120.65 & 147.57 & 146.80 & 145.98 & 121.48 & 120.77 & 128.29 \\
\hline $\begin{array}{l}\text { V. E } \\
(\mathrm{mg} / 100 \mathrm{~g})\end{array}$ & 0.236 & 0.320 & 0.764 & 0.600 & 0.711 & 0.587 & 0.804 \\
\hline $\begin{array}{l}\mathrm{V} . \mathrm{K} \\
(\mu \mathrm{g} / 100 \mathrm{~g})\end{array}$ & 0.176 & 1.330 & 0.204 & 0.312 & 1.242 & 1.351 & 0.759 \\
\hline $\begin{array}{l}\text { V.B1 (Thiamine) } \\
\text { (mg/100g) }\end{array}$ & 0.07 & 0.09 & 0.10 & 0.22 & 0.13 & 0.25 & 0.24 \\
\hline $\begin{array}{l}\text { V. B2 (Riboflavin) } \\
\text { (mg/100g) }\end{array}$ & 0.022 & 0.036 & 0.047 & 0.033 & 0.054 & 0.047 & 0.037 \\
\hline Nicotinic acid B3 (mg/100g) & 0.72 & 0.74 & 0.86 & 2.59 & 0.95 & 2.67 & 2.71 \\
\hline $\begin{array}{l}\text { V.B6 } \\
\text { (pyridoxine) } \\
\text { (mg/100g) }\end{array}$ & 0.024 & 0.041 & 0.018 & 0.260 & 0.041 & 0.280 & 0.263 \\
\hline $\begin{array}{l}\text { V.B9 } \\
\text { (Folic Acid ) } \\
(\mu \mathrm{g} / \mathbf{1 0 0 g})\end{array}$ & 15.09 & 36.35 & 15.27 & 16.67 & 36.24 & 38.54 & 17.19 \\
\hline $\begin{array}{l}\text { V.B } 12 \text { (Cyanocobalamin) } \\
(\mu \mathrm{g} / 100 \mathrm{~g})\end{array}$ & 0.00 & 0.003 & 0.003 & 0.003 & 0.00 & 0.00 & 0.001 \\
\hline
\end{tabular}


Table (8): Amino Acids composition (g A.A/ $100 \mathrm{~g}$ protein) of selected biscuits (\% on dry weight basis)

\begin{tabular}{|c|c|c|c|c|c|c|c|c|c|}
\hline \multirow{2}{*}{ Amino Acids } & \multicolumn{7}{|c|}{ Biscuit's samples } & \multirow{2}{*}{\multicolumn{2}{|c|}{$\begin{array}{c}\text { FAO/WHO } \\
\text { Pattern (1991) }\end{array}$}} \\
\hline & Con & PWb & PG & PR & WbG & WbR & T3 & & \\
\hline \multicolumn{8}{|c|}{ Essential Amino Acids (EAA) } & Child & Adult \\
\hline Histidine & 3.15 & 3.21 & 3.18 & 2.93 & 3.07 & 4.18 & 2.88 & 1.9 & 1.6 \\
\hline Lysine & 3.41 & 3.57 & 2.64 & 2.79 & 4.17 & 4.29 & 3.47 & 5.8 & 1.6 \\
\hline Isoleucine & 4.46 & 4.53 & 4.37 & 4.20 & 4.28 & 4.52 & 4.36 & 2.8 & 1.3 \\
\hline Leucine & 7.60 & 7.75 & 7.69 & 7.63 & 7.69 & 7.80 & 7.70 & 6.6 & 1.9 \\
\hline Methionine & 2.09 & 1.66 & 1.72 & 1.78 & 1.75 & 1.81 & 2.23 & & \\
\hline Cysteine & 2.35 & 1.91 & 1.98 & 2.54 & 1.86 & 1.69 & 1.11 & & \\
\hline Methionine + Cysteine & 4.44 & 3.57 & 3.70 & 4.32 & 3.61 & 3.50 & 3.34 & 2.5 & 1.7 \\
\hline Phenylalanine & 5.13 & 5.95 & 5.83 & 5.86 & 5.93 & 6.10 & 5.21 & & \\
\hline Tyrosine & 4.20 & 4.29 & 4.78 & 4.45 & 4.28 & 4.18 & 3.83 & & \\
\hline $\begin{array}{l}\text { Phenylalanine+ } \\
\text { Tyrosine }\end{array}$ & 9.33 & 10.24 & 10.61 & 10.31 & 10.21 & 10.28 & 9.04 & 6.3 & 1.9 \\
\hline Threonine & 3.01 & 3.33 & 3.18 & 3.13 & 3.39 & 3.61 & 3.91 & 3.4 & 0.9 \\
\hline Valine & 4.50 & 5.48 & 5.44 & 5.47 & 5.37 & 5.43 & 5.46 & 3.5 & 1.3 \\
\hline Tryptophan & - & - & - & - & - & - & - & 1.1 & 0.5 \\
\hline $\begin{array}{l}\text { Total (without } \\
\text { histidine) }\end{array}$ & 36.75 & 38.47 & 37.63 & 37.85 & 38.72 & 39.43 & 37.28 & 32.0 & 11.1 \\
\hline Total EAA & 39.90 & 41.48 & 40.81 & 40.78 & 41.79 & 43.61 & 40.16 & 33.9 & 12.7 \\
\hline \multicolumn{10}{|c|}{ Non-Essential Amino Acids (NEAA) } \\
\hline Arginine & 4.59 & 5.12 & 4.91 & 4.96 & 5.27 & 5.76 & 5.09 & & \\
\hline Aspartic acid & 5.78 & 7.38 & 6.36 & 6.62 & 7.03 & 7.57 & 7.02 & & \\
\hline Serine & 4.20 & 4.76 & 4.78 & 3.81 & 5.15 & 5.53 & 6.09 & & \\
\hline Glutamic acid & 23.29 & 22.44 & 22.56 & 23.57 & 21.97 & 18.55 & 22.79 & & \\
\hline Proline & 11.11 & 8.34 & 9.28 & 8.66 & 8.12 & 8.14 & 7.92 & & \\
\hline Glycine & 3.93 & 3.81 & 3.97 & 3.97 & 3.84 & 3.85 & 3.75 & & \\
\hline Alanine & 4.32 & 4.29 & 4.50 & 5.09 & 4.28 & 4.40 & 4.58 & & \\
\hline Total NEAA & 57.22 & 56.14 & 56.36 & 56.68 & 55.66 & 53.80 & 57.14 & & \\
\hline Total AA & 97.12 & 97.62 & 97.17 & 97.46 & 97.45 & 97.41 & 97.30 & & \\
\hline PER & 3.62 & 3.83 & 3.75 & 3.75 & 3.80 & 3.85 & 3.82 & & \\
\hline BV & 88.01 & 90.22 & 89.39 & 89.38 & 89.91 & 90.44 & 90.12 & & \\
\hline
\end{tabular}

*Tryptophan was not determined.

From aforementioned data recorded in Table (8), it could be also observed that all essential amino acids of control and other produced supplemented biscuits had values higher than those of pattern recommended by FAO/WHO (1991) for adults, and also for the child except for lysine and Threonine for most samples.

These results were in agreement with those of Madsen (2008) who mentioned that protein of rice bran is appraised as a high-grade protein due to the variation of amino acids and types of protein in the crude extract. In addition combinations of legumes and cereals provide better overall essential amino acid balance (Boye et al., 2010).

Fatty acids content of supplemented biscuit:

Fatty acids composition of resultant biscuits are given in Table (9). From the obtained results, it could be observed that Palmitic acid was the major saturated fatty 
acid (SFA) compared with other SFA in all samples of biscuits. While oleic acid and linoleic acid were the major unsaturated fatty acid (UFA) compared with other UFA. All samples of supplemented biscuits had the highest value of UFA and lowest value of SFA compared with control sample. The highest total unsaturated fatty acids contents $(46.29 \%)$ are given in sample PG followed by $\mathrm{WbR}(45.64 \%)$ then $\mathrm{PWb}$ $(45.35 \%)$.

A low intake of saturated fat and an increased unsaturated to saturated fatty acid ratio are associated with a low risk of human coronary heart disease $(\mathrm{Hu}$ et al., 1997; 1999).

Table (9): Fatty acids composition (\% oils of the sample) extracted from supplemented biscuits

\begin{tabular}{|c|c|c|c|c|c|c|c|}
\hline \multirow{2}{*}{ Fatty Acids } & \multicolumn{7}{|c|}{ Biscuit's samples } \\
\hline & Con. & $\mathbf{P W b}$ & PG & PR & WbG & WbR & T3 \\
\hline \multicolumn{8}{|c|}{ Saturated Fatty Acids (SFA) } \\
\hline C4:0 Butyric acid & 1.46 & 0.23 & 0.16 & 1.12 & 0.64 & 1.11 & 0.68 \\
\hline C6:0 Caproic acid & 1.66 & 0.49 & 1.16 & 1.35 & 1.45 & 1.28 & 1.44 \\
\hline C8:0 Caprylic acid & 1.10 & 0.41 & 0.81 & 0.90 & 0.99 & 0.85 & 0.97 \\
\hline C10:0 Capric acid & 2.57 & 1.24 & 1.94 & 2.19 & 2.37 & 2.01 & 2.24 \\
\hline C11:0 Undeconic acid & - & - & 0.08 & 0.08 & 0.06 & 0.06 & - \\
\hline C12:0 Lauric acid & 4.01 & 2.79 & 3.49 & 3.95 & 4.15 & 3.47 & 2.64 \\
\hline C13:0 Brassylic acid & 0.07 & 0.06 & 0.26 & 0.27 & 0.25 & 0.19 & 0.06 \\
\hline C14:0 Myristic acid & 9.80 & 8.32 & 8.07 & 9.38 & 9.60 & 8.17 & 8.60 \\
\hline C15:0 Pentadecanoic acid & 0.83 & 0.92 & 0.77 & 0.96 & 0.26 & 0.78 & 0.72 \\
\hline C16:0 Palmitic acid & 29.34 & 26.67 & 24.19 & 26.17 & 26.22 & 24.01 & 27.80 \\
\hline C17:0 Margaric acid & 0.77 & 0.68 & 0.51 & 0.70 & 0.58 & 0.52 & 0.51 \\
\hline C18:0 Stearic acid & 9.92 & 8.96 & 7.66 & 8.69 & 8.42 & 7.65 & 8.91 \\
\hline C20:0 Arachidic acid & 0.25 & 0.29 & 0.30 & 0.22 & 0.25 & 0.26 & 0.23 \\
\hline C22:0 Behenic acid & 0.10 & 0.24 & 00.0 & 0.17 & 00.0 & 0.15 & 0.11 \\
\hline $\begin{array}{l}\text { Total saturated fatty } \\
\text { Acids (TSFA) }\end{array}$ & 61.88 & 51.30 & 49.40 & 56.15 & 55.98 & 50.71 & 54.06 \\
\hline \multicolumn{8}{|c|}{ Mono unsaturated Fatty Acids (MUFA) } \\
\hline C14:1Tetradeconic Acid & 0.86 & 0.87 & 0.29 & 0.37 & 0.33 & 0.28 & 0.75 \\
\hline $\begin{array}{l}\text { C15:1 14, Pentadecenooic } \\
\text { Acid }\end{array}$ & 0.28 & 0.20 & 0.29 & 0.27 & 0.26 & 0.16 & 0.18 \\
\hline $\begin{array}{l}\text { C16:19Hexadecenoic } \\
\text { Acid }\end{array}$ & 1.77 & 1.72 & 1.24 & 1.44 & 1.41 & 1.22 & 1.65 \\
\hline $\begin{array}{l}\text { C17:1 Heptadecenoic } \\
\text { Acid }\end{array}$ & 0.43 & 0.41 & 0.21 & 0.32 & 0.25 & 0.22 & 0.23 \\
\hline C18:1 Oleic acid & 23.24 & 26.20 & 25.03 & 23.80 & 23.52 & 24.86 & 26.74 \\
\hline C20:1 Gadoleic & 0.38 & 0.32 & 0.25 & 0.24 & 0.23 & 0.24 & 0.30 \\
\hline $\begin{array}{l}\text { Total Mono unsaturated } \\
\text { fatty Acids (TMUFA) }\end{array}$ & 26.96 & 29.72 & 27.31 & 26.44 & 26.00 & 26.98 & 29.85 \\
\hline \multicolumn{8}{|c|}{ Poly unsaturated Fatty Acids (PUFA) } \\
\hline C18:2 linoleic acid & 5.88 & 12.90 & 17.47 & 10.42 & 11.69 & 16.77 & 11.35 \\
\hline C18:2 T linoleic acid & 1.04 & 1.51 & 0.61 & 0.73 & 0.72 & 0.84 & 0.83 \\
\hline C18:3 n-6 linolenic acid & 0.29 & 0.28 & 0.09 & 0.10 & 0.10 & 0.09 & 0.20 \\
\hline C18:3 n-3 Linolenic acid & 0.95 & 0.94 & 0.73 & 0.73 & 0.92 & 0.88 & 0.72 \\
\hline C20:4 Arachidonic acid & - & - & 0.08 & 0.11 & 0.13 & 0.08 & - \\
\hline $\begin{array}{l}\text { Total Poly unsaturated } \\
\text { Fatty Acids (TPUFA) }\end{array}$ & 8.16 & 15.63 & 18.95 & 12.09 & 13.56 & 18.66 & 13.10 \\
\hline $\begin{array}{l}\text { Total Unsaturated Fatty } \\
\text { Acids (TUFA) }\end{array}$ & 35.12 & 45.35 & 46.29 & 38.53 & 39.56 & 45.64 & 42.95 \\
\hline Total Fatty Acids & 97.00 & 96.65 & 95.69 & 94.68 & 95.54 & 96.35 & 97.01 \\
\hline Unknown & 3.00 & 3.05 & 4.31 & 5.25 & 4.46 & 3.65 & 2.80 \\
\hline total & 100.0 & 99.70 & 100.0 & 99.93 & 100.0 & 100.0 & 99.81 \\
\hline
\end{tabular}


Color measurements of selected mixed sweet biscuits:

Color is a vital quality attribute of foods and plays an important role in sensory and consumer acceptance of products which exists by Millard reaction during biscuit baking (Purlis, 2010).

The changes in the external color of resultant biscuits as influenced by supplementation of different suggested raw materials were studied and the obtained results are shown in Table (10).

It could be demonstrated that PG sample had the highest values of lightness $(L)$, yellowness $(b)$ and chroma (c) (70.17, 43.80 and 44.37, respectively.), while sample T3 had the lowest value of lightness $(l)$, yellowness $(b)$, chroma $(c)$, and hue angle $(h)(59.37$, $23.56,23.78$ and 82.11 , respectively) in comparison with control samples and other samples. WbR sample had the highest value of redness $(a)$, while WbG sample had the lowest value of redness in comparison with control samples and other samples. The color intensity is related with many factors: the baking time of the dough; the contact and temperature in the baking plates or the colors formulation of raw materials, thus different colors originate were found (Purlis, 2010). The color of the top surface cookies was generated in the baking process possibly due to non-enzymatic browning (Maillard reactions) between reducing sugars and amino acids, but also possibly to starch dextrinisation and sugar caramelisation (Chevallier et al., 2000). It has also been reported that protein content has a negative correlation with the whiteness (Chevallier et al., 2000). The yellow color in the biscuit samples of PG, PR, and $\mathrm{PWbis}$ due to the presence of carotenoids in pumpkin in their biscuit blends.

Table (10): Color measurements of selected sweet biscuits

\begin{tabular}{|c|c|c|c|c|c|c|c|}
\hline \multirow{2}{*}{ Parameters } & \multicolumn{7}{|c|}{ Biscuit's samples } \\
\hline & Con & PG & PR & PWb & WbG & WbR & T3 \\
\hline Lightness $\left(L^{*}\right)$ & $\begin{array}{c}69.10^{\mathrm{ab}} \\
\pm 0.05\end{array}$ & $\begin{array}{l}70.17^{\mathrm{a}} \\
\pm 0.05\end{array}$ & $\begin{array}{c}67.77^{\mathrm{bc}} \\
\pm 1.62\end{array}$ & $\begin{array}{c}67.55^{\mathrm{bc}} \\
\pm 2.05\end{array}$ & $\begin{array}{l}69.71^{\mathrm{a}} \\
\pm 0.67\end{array}$ & $\begin{array}{l}65.97^{\mathrm{c}} \\
\pm 0.00\end{array}$ & $\begin{array}{l}59.37^{\mathrm{d}} \\
\pm 0.25\end{array}$ \\
\hline Redness $\left(a^{*}\right)$ & $\begin{array}{l}2.73^{b c} \\
\pm 0.24\end{array}$ & $\begin{array}{l}2.67^{\mathrm{cd}} \\
\pm 0.054\end{array}$ & $\begin{array}{l}2.76^{\mathrm{ab}} \\
\pm 0.68\end{array}$ & $\begin{array}{l}3.05^{\mathrm{ab}} \\
\pm 0.06\end{array}$ & $\begin{array}{l}2.32^{\mathrm{c}} \\
\pm 0.04\end{array}$ & $\begin{array}{l}3.48^{\mathrm{a}} \\
\pm 0.25\end{array}$ & $\begin{array}{l}3.21^{\mathrm{ab}} \\
\pm 0.47\end{array}$ \\
\hline Yellowness $\left(b^{*}\right)$ & $\begin{array}{l}27.64^{\mathrm{d}} \\
\pm 0.15\end{array}$ & $\begin{array}{l}43.80^{\mathrm{a}} \\
\pm 0.59\end{array}$ & $\begin{array}{l}42.17^{b} \\
\pm 0.25\end{array}$ & $\begin{array}{l}42.23^{b} \\
\pm 0.61\end{array}$ & $\begin{array}{l}34.17^{\mathrm{c}} \\
\pm 0.68\end{array}$ & $\begin{array}{l}34.37^{\mathrm{c}} \\
\pm 0.15\end{array}$ & $\begin{array}{l}23.56^{\mathrm{e}} \\
\pm 0.60\end{array}$ \\
\hline $\begin{array}{l}\text { Chroma } \\
\left(c^{*}\right)\end{array}$ & $\begin{array}{l}34.77^{\mathrm{c}} \\
\pm 0.18\end{array}$ & $\begin{array}{l}44.37^{\mathrm{a}} \\
\pm 0.37\end{array}$ & $\begin{array}{l}41.11^{b} \\
\pm 0.79\end{array}$ & $\begin{array}{l}44.15^{\mathrm{a}} \\
\pm 0.02\end{array}$ & $\begin{array}{l}34.52^{c} \\
\pm 0.42\end{array}$ & $\begin{array}{l}35.32^{\mathrm{c}} \\
\pm 0.81\end{array}$ & $\begin{array}{l}23.78^{\mathrm{d}} \\
\pm 0.09\end{array}$ \\
\hline hue angle $\left(h^{\circ}\right)$ & $\begin{array}{l}85.23^{\mathrm{c}} \\
\pm 0.33\end{array}$ & $\begin{array}{l}87.21^{\mathrm{a}} \\
\pm 0.16\end{array}$ & $\begin{array}{l}86.31^{\mathrm{b}} \\
\pm 0.30\end{array}$ & $\begin{array}{l}86.19^{b} \\
\pm 0.37\end{array}$ & $\begin{array}{l}87.31^{\mathrm{a}} \\
\pm 0.42\end{array}$ & $\begin{array}{l}81.81^{\mathrm{d}} \\
\pm 0.94\end{array}$ & $\begin{array}{l}82.11^{\mathrm{d}} \\
\pm 0.06\end{array}$ \\
\hline
\end{tabular}

Values are mean of three replicates \pm SD.

The number in the same column followed by the same letter are not significantly different at 0.05 .

$L^{*}$ (Lightness with $L=100$ for lightness, and $L=$ zero for darkness), $a^{*}$ [(chromaticity on a green $(-)$ to red $\left.(+)\right], b^{*}[$ (chromaticity on a blue $(-)$ yellow $(+)], c^{*}$ (color saturation), $\boldsymbol{h}^{\circ}$ (hue angle where $0=$ red to purple, $90^{\circ}=$ yellow, $180=$ blush to green and $270=$ blue scale.

\section{Moisture content and Physical properties of selected mixed sweet biscuits:}

Table (11), showed that moisture content of the different samples(as indicated by crispy) was found to vary between $3.34 \%$ forT3sample and $5.12 \%$ for $\mathrm{PWb}$ sample compared with $3.44 \%$ for the control, and this may be due to the difference in water holding capacity and also to the composition of different formulas of these samples. The water activity $\left(a_{w}\right)$ values of biscuit samples were in the range of 0.17 for $\mathrm{WbR}$ sample to 0.31 for PG sample compared with 0.20 for control. The drying process in biscuit manufacturing contributes to decreasing of the water activity. The water activity values of the biscuit indicate that values are in the safe range of keeping the quality. The water activity values of the biscuits are below the recommended water activity requirements for the growth of bacteria $\left(a_{w}>\right.$ $0.91)$ and molds $\left(a_{w}>0.81\right)$. In addition to influencing microbial spoilage, water activity can play a significant role in determining the activity of enzymes and vitamins in foods and can have a major impact on their color، taste, and aroma (Chirife et al., 1996). A sample of biscuits are consider non-potentially hazardous because they had water activity less than 0.6 (Bolandi et al., 2008).

Spread ratio was calculated by dividing diameter by thickness. Thus, thicker biscuit will have lower spread ratio than a thinner biscuit, provided that the diameters of both biscuits are not significantly different. Lesser Spread ratio value of $6.62 \%$ was observed in the case of the control sample. Cookies with a higher value of spread ratio are more desirable (Eissa et al. 2007; Hussein et al., 2013).

Specific volume for produced types of biscuit was ranged from $5.33 \mathrm{~cm}^{3} / \mathrm{g}$ for $\mathrm{T} 3$ to $6.95 \mathrm{~cm}^{3} / \mathrm{g}$ for $\mathrm{PG}$ compared with $7.69 \mathrm{~cm}^{3} / \mathrm{g}$ for control. Also, the data outlined in the same Table represented that hardness of biscuit was significantly affected, except in the case of 
PG sample. The lesser hardness values of 36.67 and $36.96 \mathrm{~N}$ were observed in control and PG samples, respectively. Hardness (breaking strength) measures the maximum force applied by the instrument to snap the biscuit into two pieces, thereby indicates the hardness of the biscuit. Hence, higher value indicates that the biscuit is harder. These results agreed with Hoojjat and Zabik
(1984) and Lee; Beuchat (1991) who reported that more strength was needed to break cookies incorporated with legumes flour. This might have resulted from the incorporation of protein-rich flour which need more water to obtain good cookie dough, and the cookies prepared from high-absorption dough tend to be extremely hard.

Table (11): Moisture content and physical properties of selected sweet biscuits

\begin{tabular}{|c|c|c|c|c|c|c|c|}
\hline \multirow{2}{*}{ Parameters } & \multicolumn{7}{|c|}{ Biscuit's samples } \\
\hline & Con & $\mathbf{P W b}$ & PG & PR & WbG & WbR & T3 \\
\hline Moisture (\%) & $\begin{array}{l}3.44^{\mathrm{cd}} \\
\pm 0.46\end{array}$ & $\begin{array}{l}5.12^{\mathrm{a}} \\
\pm 0.21\end{array}$ & $\begin{array}{l}4.26^{\mathrm{b}} \\
\pm 0.33\end{array}$ & $\begin{array}{l}3.72^{\mathrm{c}} \\
\pm 0.13\end{array}$ & $\begin{array}{l}3.89^{\mathrm{bc}} \\
\pm 0.06\end{array}$ & $\begin{array}{l}3.38^{\mathrm{d}} \\
\pm 0.08\end{array}$ & $\begin{array}{l}3.34^{\mathrm{d}} \\
\pm 0.25\end{array}$ \\
\hline Water activity $\left(a_{w}\right)$ & $\begin{array}{l}0.20^{\mathrm{c}} \\
\pm 0.01\end{array}$ & $\begin{array}{c}0.30^{\mathrm{a}} \\
\pm 0.04\end{array}$ & $\begin{array}{l}0.31^{\mathrm{a}} \\
\pm 0.00\end{array}$ & $\begin{array}{l}0.29^{\mathrm{ab}} \\
\pm 0.00\end{array}$ & $\begin{array}{l}0.20^{\mathrm{c}} \\
\pm 0.01\end{array}$ & $\begin{array}{c}0.17^{\mathrm{d}} \\
\pm 0.00\end{array}$ & $\begin{array}{c}0.27^{\mathrm{b}} \\
\pm 0.00\end{array}$ \\
\hline Diameter (mm) & $\begin{array}{l}39.69^{\mathrm{b}} \\
\pm 0.06\end{array}$ & $\begin{array}{l}41.07^{\mathrm{a}} \\
\pm 0.69\end{array}$ & $\begin{array}{l}41.06^{\mathrm{a}} \\
0.19 \pm\end{array}$ & $\begin{array}{c}40.07^{\mathrm{ab}} \\
\pm 0.69\end{array}$ & $\begin{array}{l}38.26^{\mathrm{c}} \\
\pm 1.38\end{array}$ & $\begin{array}{c}40.69^{\mathrm{ab}} \\
\pm 0.07\end{array}$ & $\begin{array}{l}39.63^{b} \\
\pm 0.00\end{array}$ \\
\hline Thickness (mm) & $\begin{array}{c}6.00^{\mathrm{a}} \\
\pm 0.00\end{array}$ & $\begin{array}{l}5.67^{\mathrm{ab}} \\
\pm 0.35\end{array}$ & $\begin{array}{l}5.75^{\mathrm{ab}} \\
\pm 0.25\end{array}$ & $\begin{array}{l}5.75^{\mathrm{ab}} \\
\pm 0.25\end{array}$ & $\begin{array}{l}5.17^{\mathrm{c}} \\
\pm 0.35\end{array}$ & $\begin{array}{l}5.37^{\mathrm{bc}} \\
\pm 0.13\end{array}$ & $\begin{array}{c}4.5^{\mathrm{d}} \\
\pm 0.25\end{array}$ \\
\hline Spread ratio (\%) & $\begin{array}{l}6.62^{\mathrm{c}} \\
\pm 0.01\end{array}$ & $\begin{array}{l}7.26^{\mathrm{bc}} \\
\pm 0.33\end{array}$ & $\begin{array}{l}7.15^{\mathrm{bc}} \\
\pm 0.35\end{array}$ & $\begin{array}{l}6.97^{\mathrm{bc}} \\
\pm 0.19\end{array}$ & $\begin{array}{l}7.44^{\mathrm{b}} \\
\pm 0.78\end{array}$ & $\begin{array}{l}7.59^{b} \\
\pm 0.19\end{array}$ & $\begin{array}{l}8.83^{\mathrm{a}} \\
\pm 0.50\end{array}$ \\
\hline Spread factor & $\begin{array}{c}100^{\mathrm{d}} \\
\pm 0.00\end{array}$ & $\begin{array}{c}110.22^{\mathrm{bc}} \\
\pm 4.82\end{array}$ & $\begin{array}{c}108.01^{\mathrm{bcd}} \\
\pm 5.37\end{array}$ & $\begin{array}{c}105.34^{\mathrm{cd}} \\
\pm 2.96\end{array}$ & $\begin{array}{c}115.38^{\mathrm{ab}} \\
\pm 1.23\end{array}$ & $\begin{array}{c}114.60^{\mathrm{abc}} \\
\pm 2.99\end{array}$ & $\begin{array}{c}120.89^{\mathrm{a}} \\
\pm 1.58\end{array}$ \\
\hline Weight (g) & $\begin{array}{l}4.26^{\mathrm{d}} \\
\pm 0.09\end{array}$ & $\begin{array}{l}5.11^{\mathrm{a}} \\
\pm 0.30\end{array}$ & $\begin{array}{l}4.61^{b c d} \\
\pm 0.23\end{array}$ & $\begin{array}{l}4.83^{\mathrm{ab}} \\
\pm 0.21\end{array}$ & $\begin{array}{l}4.42^{\text {cd }} \\
\pm 0.25\end{array}$ & $\begin{array}{l}4.77^{\mathrm{abc}} \\
\pm 0.04\end{array}$ & $\begin{array}{l}4.27^{\mathrm{d}} \\
\pm 0.33\end{array}$ \\
\hline Volume $\left(\mathrm{cm}^{3}\right)$ & $\begin{array}{l}32.75^{\mathrm{a}} \\
\pm 0.25\end{array}$ & $\begin{array}{l}32.75^{\mathrm{a}} \\
\pm 0.25\end{array}$ & $\begin{array}{l}32.0^{\mathrm{a}} \\
\pm 1.00\end{array}$ & $\begin{array}{l}31.50^{\mathrm{a}} \\
\pm 1.50\end{array}$ & $\begin{array}{l}25.77^{\mathrm{c}} \\
\pm 0.25\end{array}$ & $\begin{array}{l}29.0^{\mathrm{b}} \\
\pm 0.50\end{array}$ & $\begin{array}{l}22.75^{\mathrm{d}} \\
\pm 1.75\end{array}$ \\
\hline $\begin{array}{l}\text { Specific volume } \\
\left(\mathrm{cm}^{3} / \mathrm{g}\right)\end{array}$ & $\begin{array}{l}7.69^{\mathrm{a}} \\
\pm 0.10\end{array}$ & $\begin{array}{l}6.43^{\mathrm{cd}} \\
\pm 0.43\end{array}$ & $\begin{array}{l}6.95^{\mathrm{b}} \\
\pm 0.13\end{array}$ & $\begin{array}{l}6.52^{\mathrm{c}} \\
\pm 0.03\end{array}$ & $\begin{array}{l}5.85^{\mathrm{e}} \\
\pm 0.39\end{array}$ & $\begin{array}{l}6.09^{\mathrm{de}} \\
\pm 0.15\end{array}$ & $\begin{array}{l}5.33^{\mathrm{f}} \\
\pm 0.00\end{array}$ \\
\hline Hardness (N) & $\begin{array}{l}36.67^{\mathrm{c}} \\
\pm 0.66\end{array}$ & $\begin{array}{l}60.57^{\mathrm{a}} \\
\pm 1.70\end{array}$ & $\begin{array}{l}36.96^{\mathrm{c}} \\
\pm 0.10\end{array}$ & $\begin{array}{c}48.87^{\mathrm{abc}} \\
\pm 1.24\end{array}$ & $\begin{array}{l}39.64^{\mathrm{bc}} \\
\pm 1.41\end{array}$ & $\begin{array}{l}51.17^{\mathrm{ab}} \\
\pm 1.00\end{array}$ & $\begin{array}{l}47.93^{b c} \\
\pm 0.56\end{array}$ \\
\hline
\end{tabular}

Values are mean $\pm \mathrm{SD}$.

Each value with the same row is followed by the same letters is not significantly different at the level of 0.05 .

Changes in Peroxide values (PV) of biscuit lipids during storage at room temperature $\left(20-25^{\circ} \mathrm{C}\right)$.

Peroxide value (PV) is an indicator for measuring oxidative deterioration of lipids and it's a good index for the quality of fat. Refined fats should have PV of less than 1 milli equivalent peroxide/Kg fats and fat that has been stored for some period of time after refining may have PV of up to 10 milli equivalent peroxide $/ \mathrm{Kg}$ fats (Allen, 1983). The peroxide value estimated after baking, then during storage for2, 4 and 6 months is recorded in Table (12). The results revealed that the PV of all resultant biscuits increased with the increase of storage period up to 6 months. At the end of the storage period, the P.V value of all biscuits were lower than the permissible value (10 peroxide/ $\mathrm{Kg}$ fats according to the Egyptian Specification standard No 416 (2003). The PV of all biscuit samples at the end of storage period were lower than that of control except $\mathrm{WbG}$ and $\mathrm{T} 3$ samples.
And the PR and WbR samples have the lowest value of $\mathrm{PV}$ at the end of storage period. These are due to deferent their content of the antioxidant (Priecinaand Karklina, 2014).

Changes in acid value (AV) of biscuit lipids during storage at room temperature $\left(20-25^{\circ} \mathrm{C}\right)$ :

The changes occurred in the A.V of biscuit lipids extracted from different biscuit treatment during the storage period of biscuit at room temperature are shown in Table (12). The AV for produced types of biscuit were ranged from 1.00 to $3.35 \mathrm{mg} \mathrm{KOH} / \mathrm{g}$ lipid after baking compared with $1.17 \mathrm{mg} \mathrm{KOH} / \mathrm{g}$ lipid for control, and from 3.30 to $5.37 \mathrm{KOH} / \mathrm{g}$ lipid at the end of storage period compared with $2.34 \mathrm{mg} \mathrm{KOH} / \mathrm{g}$ lipid for control. While the acid value of control and treatments increased at the end storage period, these are due to the moisture content increased. 
Table (12): Changes in peroxide value and acid value of resultant sweet biscuit during storage at room temperature $\left(20-25^{\circ} \mathrm{C}\right)$

\begin{tabular}{|c|c|c|c|c|c|c|c|c|}
\hline \multirow{3}{*}{$\begin{array}{l}\text { Type of } \\
\text { biscuit }\end{array}$} & \multicolumn{4}{|c|}{ PV* } & \multicolumn{4}{|c|}{$\mathbf{A V} * *$} \\
\hline & \multicolumn{4}{|c|}{ Storage period after } & \multicolumn{4}{|c|}{ Storage period after } \\
\hline & $\begin{array}{c}\text { After } \\
\text { baking }\end{array}$ & $\begin{array}{c}2 \\
\text { Month }\end{array}$ & $\begin{array}{c}4 \\
\text { months }\end{array}$ & $\begin{array}{c}6 \\
\text { months }\end{array}$ & $\begin{array}{c}\text { After } \\
\text { baking }\end{array}$ & $\begin{array}{c}2 \\
\text { months }\end{array}$ & $\begin{array}{c}4 \\
\text { months }\end{array}$ & $\begin{array}{c}6 \\
\text { months }\end{array}$ \\
\hline Control & $\begin{array}{l}4.63^{b c} \\
\pm 0.13\end{array}$ & $\begin{array}{l}4.65^{\mathrm{d}} \\
\pm 0.26\end{array}$ & $\begin{array}{l}5.39^{\mathrm{f}} \\
\pm 0.30\end{array}$ & $\begin{array}{l}8.12^{\mathrm{b}} \\
\pm 0.06\end{array}$ & $\begin{array}{l}1.17^{\mathrm{de}} \\
\pm 0.11\end{array}$ & $\begin{array}{c}1.23^{\mathrm{f}} \\
\pm 0.15\end{array}$ & $\begin{array}{l}2.30^{\mathrm{d}} \\
\pm 0.10\end{array}$ & $\begin{array}{l}2.34^{\mathrm{d}} \\
\pm 0.26\end{array}$ \\
\hline PWb & $\begin{array}{c}4.40^{\mathrm{e}} \\
\pm 0.10\end{array}$ & $\begin{array}{c}7.80^{b} \\
\pm 0.15\end{array}$ & $\begin{array}{l}7.94^{\mathrm{b}} \\
\pm 0.07\end{array}$ & $\begin{array}{l}8.00^{\mathrm{b}} \\
\pm 1.00\end{array}$ & $\begin{array}{l}1.00^{\mathrm{e}} \\
\pm 0.50\end{array}$ & $\begin{array}{l}2.33^{\mathrm{de}} \\
\pm 0.08\end{array}$ & $\begin{array}{l}2.98^{\mathrm{c}} \\
\pm 0.03\end{array}$ & $\begin{array}{l}3.30^{\mathrm{c}} \\
\pm 1.10\end{array}$ \\
\hline PG & $\begin{array}{l}4.67^{b} \\
\pm 0.03\end{array}$ & $\begin{array}{l}6.20^{\mathrm{c}} \\
\pm 0.10\end{array}$ & $\begin{array}{l}7.26^{\mathrm{c}} \\
\pm 0.04\end{array}$ & $\begin{array}{l}8.10^{\mathrm{b}} \\
\pm 0.10\end{array}$ & $\begin{array}{l}2.67^{\mathrm{b}} \\
\pm 0.03\end{array}$ & $\begin{array}{l}2.67^{\mathrm{c}} \\
\pm 0.02\end{array}$ & $\begin{array}{c}3.56^{\mathrm{b}} \\
\pm 0.09\end{array}$ & $\begin{array}{l}3.61^{\mathrm{c}} \\
\pm 0.11\end{array}$ \\
\hline PR & $\begin{array}{l}4.30^{\mathrm{e}} \\
\pm 0.10\end{array}$ & $\begin{array}{l}6.00^{\mathrm{c}} \\
\pm 1.00\end{array}$ & $\begin{array}{l}6.22^{\mathrm{e}} \\
\pm 0.10\end{array}$ & $\begin{array}{l}\mathbf{6 . 7 0} \\
\pm 0.10\end{array}$ & $\begin{array}{l}2.14^{\mathrm{bc}} \\
\pm 0.06\end{array}$ & $\begin{array}{l}3.20^{\mathrm{b}} \\
\pm 0.10\end{array}$ & $\begin{array}{c}4.08^{\mathrm{a}} \\
\pm 0.01\end{array}$ & $\begin{array}{l}5.37^{\mathrm{a}} \\
\pm 0.11\end{array}$ \\
\hline WbG & $\begin{array}{l}4.54^{\text {bcd }} \\
\pm 0.06\end{array}$ & $\begin{array}{l}6.20^{\mathrm{c}} \\
\pm 0.10\end{array}$ & $\begin{array}{l}8.71^{\mathrm{a}} \\
\pm 0.05\end{array}$ & $\begin{array}{l}9.69^{\mathrm{a}} \\
\pm 0.11\end{array}$ & $\begin{array}{l}2.10^{\mathrm{c}} \\
\pm 0.10\end{array}$ & $\begin{array}{l}2.47^{\mathrm{d}} \\
\pm 0.14\end{array}$ & $\begin{array}{l}2.89^{\mathrm{c}} \\
\pm 0.05\end{array}$ & $\begin{array}{l}3.40^{\mathrm{c}} \\
\pm 0.10\end{array}$ \\
\hline WbR & $\begin{array}{l}6.11^{\mathrm{a}} \\
\pm 0.03\end{array}$ & $\begin{array}{l}6.56^{\mathrm{c}} \\
\pm 0.11\end{array}$ & $\begin{array}{l}6.90^{\mathrm{d}} \\
\pm 0.10\end{array}$ & $\begin{array}{l}7.31^{\mathrm{c}} \\
\pm 0.11\end{array}$ & $\begin{array}{l}3.35^{\mathrm{a}} \\
\pm 0.10\end{array}$ & $\begin{array}{l}3.63^{\mathrm{a}} \\
\pm 0.03\end{array}$ & $\begin{array}{l}4.08^{\mathrm{a}} \\
\pm 0.02\end{array}$ & $\begin{array}{l}4.59^{\mathrm{b}} \\
\pm 0.03\end{array}$ \\
\hline T3 & $\begin{array}{l}4.50^{\mathrm{cd}} \\
\pm 0.10\end{array}$ & $\begin{array}{l}8.73^{\mathrm{a}} \\
\pm 0.12\end{array}$ & $\begin{array}{l}8.86^{\mathrm{a}} \\
\pm 0.04\end{array}$ & $\begin{array}{l}9.17^{\mathrm{a}} \\
\pm 0.06\end{array}$ & $\begin{array}{l}1.43^{\mathrm{d}} \\
\pm 0.07\end{array}$ & $\begin{array}{l}2.25^{\mathrm{e}} \\
\pm 0.10\end{array}$ & $\begin{array}{l}2.30^{\mathrm{d}} \\
\pm 0.10\end{array}$ & $\begin{array}{l}3.39^{\mathrm{c}} \\
\pm 0.09\end{array}$ \\
\hline
\end{tabular}

* PV $=$ Peroxide value (milli equivalent peroxides/Kg lipid).

** $\mathrm{AV}=$ Acid values (mg KOH/g lipid).

Each value with the same row is followed by the same letters is not significantly different at the level of 0.05 .

\section{Changes occurred in sensory evaluation (Taste and odor) of resultant biscuit during storage period at room temperature $\left(20-25^{\circ} \mathrm{C}\right)$ :}

Odor and taste are considered the most important characters that affect the quality of biscuit during storage. It was evident from the data in Table (13) that the characteristics of odor and taste decreased with the increase of storage period up to 6 months for all types of resultant biscuits. All types of resultant biscuits were accepted for odor and taste except control biscuit for taste after the 4 months of storage period. And all types of resultant biscuits were accepted for odor after the 6 months of storage period. With regard to the taste, all types of resultant biscuits and control biscuit were nonaccepted except $\mathrm{WbG}, \mathrm{WbR}$, and T3 samples after the 6 months of storage period. Percentage of losses of odor for produced types of biscuit were ranged from $9.89 \%$ for $\mathrm{WbR}$ sample to $23.16 \%$ for PWb sample compared with $27.18 \%$ for control sample during storage for 6 months at room temperature. While the percentage of losses of taste for resultant types of biscuit were ranged from $14.44 \%$ for $\mathrm{WbR}$ sample to $29.68 \%$ for $\mathrm{PWb}$ sample compared with $37.17 \%$ for control sample during storage for 6 months at room temperature. In general, all samples of the resultant biscuits can be consumed within two months of production without any noticeable changes in both odor and taste.

A gradual decrease in overall acceptability of biscuit during storage was reported by Elahi (1999) who attributed it to moisture absorption, increase in peroxide value and free fatty acid contents in biscuits.

\section{Microbiological evaluation of different types of the biscuits:}

The total microbial and Yeast \& Mold count of different types of biscuits were investigated to assess one of the most important factors in the evaluation of biscuits quality. Data in Table (14) indicated that no total microbial count was detected after 2 and 4 months for all types of produced biscuit except $\mathrm{PWb}$ and $\mathrm{PG}$ samples after 4 months. After 6 months of storage at room temperature $\left(20-25^{\circ} \mathrm{C}\right)$ all types of biscuits appeared that microbial growth was detected. It's ranged from $1 \times 10^{3} \mathrm{cfu} / \mathrm{g}$ for WbR sample to $4 \times 10^{3} \mathrm{cfu} / \mathrm{g}$ for both in PWb and PR samples compared with $5 \times 10^{3} \mathrm{cfu} / \mathrm{g}$ for control. While all biscuits types appeared that no Yeast \& Mold was detected during storage period up to 6 months at room temperature except for PR sample which recorded $1 \times 10^{3} \mathrm{cfu} / \mathrm{g}$, this microbial contamination may be occur during handling preparation or worker's hands or increased temperature degree during storage (Manley2011; Manley and Clark, 2011)

According to WHO Standard (1994) the maximum permissible limits in baked products (cake, bread and biscuit) for total plate count (TPC) is $2.0 \times 10^{5} \mathrm{cfu} \mathrm{g}^{-1}$ and yeast and mold is $<1.0 \times 10^{4} \mathrm{cfu} \mathrm{g}^{-1}$. Thus, developed biscuit had a lower microbial profile (Table 14) compared to WHO Standards (1994). On the basis of these findings, it could be contended that the product is safe to consume. 
Table (13): Mean values of odor and taste for resultant biscuit during storage at room temperature $\left(20-25^{\circ} \mathrm{C}\right)$

\begin{tabular}{|c|c|c|c|c|c|c|c|c|c|c|}
\hline \multirow{3}{*}{$\begin{array}{l}\text { Type of } \\
\text { biscuits }\end{array}$} & \multicolumn{4}{|c|}{ Odor (20) } & \multirow{3}{*}{$\begin{array}{c}\% \\
\text { Losses } \\
\text { on odor* }\end{array}$} & \multirow{2}{*}{\multicolumn{4}{|c|}{$\frac{\text { Taste }(20)}{\text { Storage period (month) }}$}} & \multirow{3}{*}{$\begin{array}{l}\% \text { Losses } \\
\text { on taste** }\end{array}$} \\
\hline & \multicolumn{4}{|c|}{ Storage period (month) } & & & & & & \\
\hline & $\mathbf{0}$ & 2 & 4 & 6 & & $\mathbf{0}$ & 2 & 4 & 6 & \\
\hline Control & $\begin{array}{l}19.5^{\mathrm{a}} \\
\pm 0.71\end{array}$ & $\begin{array}{l}18.2^{\mathrm{b}} \\
\pm 0.42\end{array}$ & $\begin{array}{l}15.2^{\mathrm{b}} \\
\pm 0.79\end{array}$ & $\begin{array}{l}14.2^{\mathrm{c}} \\
\pm 0.79\end{array}$ & 27.18 & $\begin{array}{c}19.1^{\mathrm{a}} \\
\pm 1.10\end{array}$ & $\begin{array}{l}17.0^{\mathrm{b}} \\
\pm 0.00\end{array}$ & $\begin{array}{l}12.4^{\mathrm{b}} \\
\pm 2.55\end{array}$ & $\begin{array}{l}12.0^{\mathrm{c}} \\
\pm 2.26\end{array}$ & 37.17 \\
\hline $\mathbf{P W b}$ & $\begin{array}{l}19.0^{\mathrm{a}} \\
\pm 0.67\end{array}$ & $\begin{array}{l}18.6^{\mathrm{a}} \\
\pm 0.97\end{array}$ & $\begin{array}{l}17.2^{\mathrm{b}} \\
\pm 1.23\end{array}$ & $\begin{array}{l}14.6^{\mathrm{c}} \\
\pm 2.07\end{array}$ & 23.16 & $\begin{array}{l}18.2^{\mathrm{a}} \\
\pm 1.23\end{array}$ & $\begin{array}{r}17.7^{\mathrm{a}} \\
\pm 0.49\end{array}$ & $\begin{array}{l}15.2^{\mathrm{b}} \\
\pm 0.42\end{array}$ & $\begin{array}{l}12.8^{\mathrm{c}} \\
\pm 2.44\end{array}$ & 29.68 \\
\hline PG & $\begin{array}{l}18.9^{\mathrm{a}} \\
\pm 0.74\end{array}$ & $\begin{array}{l}18.3^{\mathrm{a}} \\
\pm 0.95\end{array}$ & $\begin{array}{l}16.8^{\mathrm{b}} \\
\pm 1.23\end{array}$ & $\begin{array}{l}15.0^{\mathrm{c}} \\
\pm 2.16\end{array}$ & 20.63 & $\begin{array}{l}17.75^{\mathrm{a}} \\
\pm 1.28\end{array}$ & $\begin{array}{l}17.5^{\mathrm{a}} \\
\pm 0.71\end{array}$ & $\begin{array}{l}15.4^{\mathrm{b}} \\
\pm 0.52\end{array}$ & $\begin{array}{l}12.8^{\mathrm{c}} \\
\pm 1.81\end{array}$ & 27.89 \\
\hline PR & $\begin{array}{l}18.6^{\mathrm{a}} \\
\pm 0.97\end{array}$ & $\begin{array}{l}18.3^{\mathrm{a}} \\
\pm 0.49\end{array}$ & $\begin{array}{l}16.8^{\mathrm{b}} \\
\pm 1.03\end{array}$ & $\begin{array}{l}16.4^{\mathrm{b}} \\
\pm 2.88\end{array}$ & 11.83 & $\begin{array}{l}17.4^{\mathrm{a}} \\
\pm 1.17\end{array}$ & $\begin{array}{l}17.2^{\mathrm{a}} \\
\pm 0.79\end{array}$ & $\begin{array}{l}15.6^{\mathrm{b}} \\
\pm 1.84\end{array}$ & $\begin{array}{c}13.8^{\mathrm{c}} \\
\pm 2.62\end{array}$ & 20.69 \\
\hline WbG & $\begin{array}{l}18.5^{\mathrm{a}} \\
\pm 1.27\end{array}$ & $\begin{array}{c}18.3^{\mathrm{a}} \\
\pm 1.06\end{array}$ & $\begin{array}{l}16.2^{\mathrm{b}} \\
\pm 2.94\end{array}$ & $\begin{array}{c}15.4^{\mathrm{b}} \\
\pm 1.57\end{array}$ & 16.76 & $\begin{array}{c}18.2^{\mathrm{a}} \\
\pm 0.27\end{array}$ & $\begin{array}{c}17.7^{\mathrm{a}} \\
\pm 0.82\end{array}$ & $\begin{array}{c}15.8^{\mathrm{b}} \\
\pm 1.69\end{array}$ & $\begin{array}{l}15.0^{\mathrm{b}} \\
\pm 1.89\end{array}$ & 17.56 \\
\hline WbR & $\begin{array}{l}18.2^{\mathrm{a}} \\
\pm 0.91\end{array}$ & $\begin{array}{l}17.8^{\mathrm{ab}} \\
\pm 0.63\end{array}$ & $\begin{array}{c}16.6^{\mathrm{b}} \\
\pm 1.08\end{array}$ & $\begin{array}{c}16.4^{\mathrm{b}} \\
\pm 2.80\end{array}$ & 9.89 & $\begin{array}{c}18.0^{\mathrm{a}} \\
\pm 0.82\end{array}$ & $\begin{array}{c}17.6^{\mathrm{a}} \\
\pm 0.52\end{array}$ & $\begin{array}{c}15.6^{\mathrm{b}} \\
\pm 1.08\end{array}$ & $\begin{array}{l}15.4^{\mathrm{b}} \\
\pm 1.58\end{array}$ & 14.44 \\
\hline T3 & $\begin{array}{c}18.4^{\mathrm{a}} \\
\pm 1.43\end{array}$ & $\begin{array}{c}18.3^{\mathrm{a}} \\
\pm 1.50\end{array}$ & $\begin{array}{l}15.3^{\mathrm{b}} \\
\pm 1.06\end{array}$ & $\begin{array}{c}14.8^{\mathrm{b}} \\
\pm 2.44\end{array}$ & 19.57 & $\begin{array}{c}18.1^{\mathrm{a}} \\
\pm 1.10\end{array}$ & $\begin{array}{c}17.9^{\mathrm{a}} \\
\pm 0.88\end{array}$ & $\begin{array}{c}15.0^{\mathrm{b}} \\
\pm 1.16\end{array}$ & $\begin{array}{l}14.2^{\mathrm{b}} \\
\pm 2.44\end{array}$ & 21.55 \\
\hline
\end{tabular}

Values with the same row followed by the same letters are not significantly different at the level of 0.05 .

Score $\leq 14$ non-acceptant.

Table (14): Microbiological analysis (cfu/g) of sweet biscuits during storage at room temperature $\left(20-25^{\circ} \mathrm{C}\right)$

\begin{tabular}{|c|c|c|c|c|c|c|c|c|}
\hline \multirow{3}{*}{$\begin{array}{l}\text { Type of } \\
\text { biscuit }\end{array}$} & \multicolumn{4}{|c|}{ Total plate count } & \multicolumn{4}{|c|}{ Yeast \& Mold } \\
\hline & \multicolumn{4}{|c|}{ Storage period } & \multicolumn{4}{|c|}{ Storage period } \\
\hline & $\begin{array}{l}\text { Zero } \\
\text { time }\end{array}$ & $\begin{array}{l}\text { After } 2 \\
\text { months }\end{array}$ & $\begin{array}{l}\text { After } 4 \\
\text { months }\end{array}$ & $\begin{array}{l}\text { After } 6 \\
\text { months }\end{array}$ & $\begin{array}{l}\text { Zero } \\
\text { time }\end{array}$ & $\begin{array}{l}\text { After } 2 \\
\text { months }\end{array}$ & $\begin{array}{l}\text { After } 4 \\
\text { months }\end{array}$ & $\begin{array}{l}\text { After } 6 \\
\text { months }\end{array}$ \\
\hline Con & ND & ND & ND & $5 \times 10^{3}$ & ND & ND & ND & ND \\
\hline $\mathbf{P W b}$ & ND & ND & $2 \times 10^{3}$ & $4 \times 10^{3}$ & ND & ND & ND & ND \\
\hline PG & ND & ND & $1 \times 10^{3}$ & $3 \times 10^{3}$ & ND & ND & ND & ND \\
\hline PR & ND & ND & ND & $4 \times 10^{3}$ & ND & ND & ND & $1 \times 10^{3}$ \\
\hline WbG & ND & ND & ND & $2 \times 10^{3}$ & ND & ND & ND & ND \\
\hline WbR & ND & ND & ND & $1 \times 10^{3}$ & ND & ND & ND & ND \\
\hline T3 & ND & ND & ND & $2 \times 10^{3}$ & ND & ND & ND & ND \\
\hline
\end{tabular}

*ND $=$ not detected

Percentages of the recommended dietary allowances (\%RDA) provided from resultant biscuits:

A meal in a school day is of importance from nutritionally, socially and educationally concepts. The meal should be offered at the school to provide onethird of a child's daily requirements of protein, energy, and some minerals and vitamins (Morrison, 1996).

Adequate nutrient intake, especially of protein and micronutrients, enhances the growth of children and decreases susceptibility to disease (Kebebu et al., 2013).
The percentages of the recommended dietary allowances (\% RDA) provided from $100 \mathrm{~g}$ of resultant biscuits for children and adults (males and females) are shown in Tables $(15,16$ and 17), it could be observed that all values of \% RDA for protein, energy, minerals (i.e., Iron, zinc, calcium, magnesium and manganese) and vitamins contents (i.e., A, E, K and B1, B2, B3, B6 and B9) were high in all samples of supplemented biscuits compared with control un-supplemented biscuits. 
Table (15): Percentage of the RDA of some nutrient provided from $100 \mathrm{~g}$ biscuit for children

\begin{tabular}{|c|c|c|c|c|c|c|c|c|c|}
\hline \multirow{2}{*}{ Age group } & \multirow{2}{*}{ Nutrient } & \multirow{2}{*}{ RDA* } & \multicolumn{7}{|c|}{ \% RDA from Biscuit samples** } \\
\hline & & & Control & $\mathbf{P W b}$ & PG & PR & WbG & WbR & T3 \\
\hline \multirow{17}{*}{$\begin{array}{l}\text { Children } \\
\text { (4-8) years }\end{array}$} & Carbohydrate & $130 \mathrm{~g}$ & 59.13 & 56.10 & 54.62 & 55.55 & 53.82 & 55.55 & 54.67 \\
\hline & Protein & $19 \mathrm{~g}$ & 40.00 & 47.26 & 42.74 & 44.58 & 45.63 & 46.58 & 46.21 \\
\hline & Energy & $\begin{array}{l}1742 \\
\text { K.cal }\end{array}$ & 26.44 & 27.20 & 26.98 & 26.67 & 27.34 & 26.81 & 27.45 \\
\hline & $\mathbf{F e}$ & $10 \mathrm{mg}$ & 15.0 & 23.0 & 22.1 & 31.7 & 22.5 & 33.1 & 30.1 \\
\hline & $\mathbf{Z n}$ & $5 \mathrm{mg}$ & 14.4 & 23.20 & 29.0 & 25.40 & 26.2 & 27.8 & 30.2 \\
\hline & $\mathbf{C a}$ & $1000 \mathrm{mg}$ & 1.32 & 3.11 & 1.83 & 1.92 & 2.33 & 2.39 & 2.39 \\
\hline & Mg & $130 \mathrm{mg}$ & 8.89 & 13.69 & 11.05 & 13.75 & 11.85 & 14.68 & 13.67 \\
\hline & Mn & $1.5 \mathrm{mg}$ & 24.67 & 33.33 & 18.67 & 38.00 & 32.67 & 56.00 & 54.67 \\
\hline & Vitamin A & $400 \mu \mathrm{g}$ & 30.16 & 36.89 & 36.70 & 36.50 & 30.37 & 30.19 & 32.07 \\
\hline & Vitamin E & $7 \mathrm{mg}$ & 3.37 & 4.57 & 10.91 & 8.57 & 10.16 & 8.39 & 11.49 \\
\hline & Vitamin K & $55 \mu \mathrm{g}$ & 0.32 & 2.42 & 0.37 & 0.57 & 2.26 & 2.46 & 1.38 \\
\hline & Thiamin $B_{1}$ & $6.0 \mathrm{mg}$ & 1.17 & 1.50 & 1.67 & 3.66 & 2.17 & 4.17 & 4.0 \\
\hline & Riboflavin B2 & $0.6 \mathrm{mg}$ & 3.67 & 6.0 & 7.83 & 5.5 & 9.0 & 7.83 & 6.17 \\
\hline & $\begin{array}{l}\text { Nicotinic acid } \\
\text { B3 }\end{array}$ & $8 \mathrm{mg}$ & 9.0 & 9.25 & 10.75 & 32.38 & 11.88 & 33.38 & 33.88 \\
\hline & Pyridoxine $B_{6}$ & $0.6 \mathrm{mg}$ & 4.0 & 6.83 & 3.0 & 43.33 & 6.83 & 46.67 & 43.83 \\
\hline & Folate B9 & $200 \mu \mathrm{g}$ & 7.55 & 18.18 & 7.64 & 8.34 & 18.12 & 19.27 & 8.60 \\
\hline & $\mathbf{B}_{12}$ & $1.2 \mu \mathrm{g}$ & 0.00 & 0.25 & 0.25 & 0.25 & 0.00 & 0.00 & 0.08 \\
\hline
\end{tabular}

* Recommended dietary allowances from the Dietary Reference Intakes according to Food and Nutrition Board as reports by National Academy of Sciences (2004).

$* * \% \mathrm{RDA}=$ Value of nutrient in the sample of biscuit $\times 100 / \mathrm{RDA}$ for the same nutrient.

Table (16): Percentage of the RDA of some nutrient provided from $100 \mathrm{~g}$ biscuit for males

\begin{tabular}{|c|c|c|c|c|c|c|c|c|c|}
\hline \multirow{2}{*}{ Age group } & \multirow{2}{*}{ Nutrient } & \multirow{2}{*}{ RDA* } & \multicolumn{7}{|c|}{ \% RDA from Biscuit samples** } \\
\hline & & & Control & $\mathbf{P W b}$ & PG & $\mathbf{P R}$ & WbG & WbR & T3 \\
\hline \multirow{17}{*}{$\begin{array}{c}\text { Males } \\
(14-18) \text { years }\end{array}$} & Carbohydrate & $130 \mathrm{~g}$ & 59.13 & 56.10 & 54.62 & 55.55 & 53.82 & 55.55 & 54.67 \\
\hline & Protein & $52 \mathrm{~g}$ & 14.62 & 17.27 & 15.62 & 16.29 & 16.67 & 17.02 & 16.88 \\
\hline & Energy & 3152 K.cal & 14.61 & 15.03 & 14.91 & 14.74 & 15.11 & 14.82 & 15.17 \\
\hline & $\mathbf{F e}$ & $11 \mathrm{mg}$ & 13.64 & 20.91 & 20.09 & 28.82 & 20.45 & 30.09 & 27.36 \\
\hline & Zn & $11 \mathrm{mg}$ & 6.55 & 10.55 & 13.18 & 11.55 & 11.91 & 12.64 & 13.73 \\
\hline & $\mathbf{C a}$ & $1300 \mathrm{mg}$ & 1.02 & 2.39 & 1.41 & 1.47 & 1.79 & 1.83 & 1.84 \\
\hline & Mg & $410 \mathrm{mg}$ & 2.82 & 4.34 & 3.50 & 4.36 & 3.76 & 4.65 & 4.33 \\
\hline & Mn & $2.2 \mathrm{mg}$ & 16.82 & 22.73 & 12.73 & 25.91 & 22.27 & 38.18 & 37.27 \\
\hline & Vitamin A & $900 \mu \mathrm{g}$ & 13.41 & 16.40 & 16.31 & 16.22 & 13.50 & 13.42 & 14.25 \\
\hline & Vitamin E & $15 \mathrm{mg}$ & 1.57 & 2.13 & 5.09 & 4.00 & 4.74 & 3.91 & 5.36 \\
\hline & Vitamin K & $75 \mu \mathrm{g}$ & 0.23 & 1.77 & 0.27 & 0.42 & 1.66 & 1.80 & 1.01 \\
\hline & Thiamin $\mathrm{B}_{1}$ & $1.2 \mathrm{mg}$ & 5.83 & 7.50 & 8.33 & 18.33 & 10.83 & 20.83 & 20.00 \\
\hline & Riboflavin & $1.3 \mathrm{mg}$ & 1.69 & 2.77 & 3.62 & 2.54 & 4.15 & 3.62 & 2.85 \\
\hline & $\begin{array}{l}\text { Nicotinic acid } \\
\text { B3 }\end{array}$ & $16 \mathrm{mg}$ & 4.50 & 4.63 & 5.38 & 16.19 & 5.94 & 16.69 & 16.94 \\
\hline & Pyridoxine $B_{6}$ & $1.3 \mathrm{mg}$ & 1.85 & 3.15 & 1.38 & 20.0 & 3.15 & 21.54 & 20.23 \\
\hline & Folate & $400 \mu \mathrm{g}$ & 3.77 & 9.09 & 3.82 & 4.17 & 9.06 & 9.64 & 4.30 \\
\hline & $\mathbf{B}_{12}$ & $2.4 \mu \mathrm{g}$ & 0.00 & 0.13 & 0.13 & 0.13 & 0.00 & 0.00 & 0.042 \\
\hline
\end{tabular}

* Recommended dietary allowances from the Dietary Reference Intakes according to Food and Nutrition Board as reports by National Academy of Sciences (2004).

$* * \% \mathrm{RDA}=$ Value of nutrient in the sample of biscuit $\times 100 /$ RDA for the same nutrient. 
Table (17): Percentage of the RDA of some nutrient provided from $100 \mathrm{~g}$ biscuit for females

\begin{tabular}{|c|c|c|c|c|c|c|c|c|c|}
\hline \multirow{2}{*}{ Age group } & \multirow{2}{*}{ Nutrient } & \multirow{2}{*}{ RDA* } & \multicolumn{7}{|c|}{ \% RDA from Biscuit samples** } \\
\hline & & & Control & $\mathbf{P W b}$ & PG & PR & WbG & WbR & T3 \\
\hline \multirow{17}{*}{$\begin{array}{c}\text { Females } \\
(14-18) \text { years }\end{array}$} & Carbohydrate & $130 \mathrm{~g}$ & 59.13 & 56.10 & 54.62 & 55.55 & 53.82 & 55.55 & 54.67 \\
\hline & Protein & $52 \mathrm{~g}$ & 16.52 & 19.52 & 17.65 & 18.41 & 18.85 & 19.24 & 19.09 \\
\hline & Energy & $\begin{array}{l}3152 \\
\text { K.cal }\end{array}$ & 19.45 & 20.01 & 19.85 & 19.62 & 20.11 & 19.72 & 20.19 \\
\hline & $\mathbf{F e}$ & $11 \mathrm{mg}$ & 10.0 & 15.33 & 14.73 & 21.13 & 15.0 & 22.07 & 20.07 \\
\hline & Zn & $11 \mathrm{mg}$ & 8.0 & 12.89 & 16.11 & 14.11 & 14.56 & 15.44 & 16.78 \\
\hline & $\mathbf{C a}$ & $1300 \mathrm{mg}$ & 1.02 & 2.39 & 1.41 & 1.47 & 1.79 & 1.83 & 1.84 \\
\hline & Mg & $410 \mathrm{mg}$ & 3.21 & 4.94 & 3.99 & 4.96 & 4.28 & 5.30 & 4.94 \\
\hline & Mn & $2.2 \mathrm{mg}$ & 23.13 & 31.25 & 17.50 & 35.63 & 30.63 & 52.50 & 51.25 \\
\hline & Vitamin A & $900 \mu \mathrm{g}$ & 17.24 & 21.08 & 20.97 & 20.85 & 17.35 & 17.25 & 18.33 \\
\hline & Vitamin E & $15 \mathrm{mg}$ & 1.57 & 2.13 & 5.09 & 4.00 & 4.74 & 3.91 & 5.36 \\
\hline & Vitamin $K$ & $75 \mu \mathrm{g}$ & 0.23 & 1.77 & 0.27 & 0.42 & 1.66 & 1.80 & 1.01 \\
\hline & Thiamin $B_{1}$ & $1.2 \mathrm{mg}$ & 7.0 & 9.0 & 10.0 & 22.0 & 13.0 & 25.0 & 24.0 \\
\hline & Riboflavin & $1.3 \mathrm{mg}$ & 2.2 & 3.6 & 4.7 & 3.3 & 5.4 & 4.7 & 3.7 \\
\hline & $\begin{array}{l}\text { Nicotinic acid } \\
\text { B3 }\end{array}$ & $16 \mathrm{mg}$ & 5.14 & 5.29 & 6.14 & 18.50 & 6.79 & 19.07 & 19.36 \\
\hline & Pyridoxine $\mathrm{B}_{6}$ & $1.3 \mathrm{mg}$ & 2.00 & 3.42 & 1.50 & 21,67 & 3.42 & 23.33 & 21.92 \\
\hline & Folate & $400 \mu \mathrm{g}$ & 3.77 & 9.09 & 3.82 & 4.17 & 9.06 & 9.64 & 4.30 \\
\hline & $\mathbf{B}_{12}$ & $2.4 \mu \mathrm{g}$ & 0.00 & 0.13 & 0.13 & 0.13 & 0.00 & 0.00 & 0.042 \\
\hline
\end{tabular}

* Recommended dietary allowances from the Dietary Reference Intakes according to Food and Nutrition Board as reports by National Academy of Sciences (2004).

$* * \% \mathrm{RDA}=$ Value of nutrient in the sample of biscuit $\times 100 / \mathrm{RDA}$ for the same nutrient

\section{CONCLUSION}

From this study, it could be concluded that incorporated of wheat flour with pumpkin, yellow corn germ, white kidney bean, rice bran and roselle flower rising nutritional values, minerals and vitamins content of resultant biscuits, and the best blend was found in WbR (80 \% Wheat flour 72\% extract $+10 \%$ white kidney bean $+10 \%$ heat stabilization rice bran). Newly prepared biscuits could be recommended as a food aid in institutional feeding programs for pupils in different school stages and adults as well. Also, it is easily to prepare by mothers at home to their family as a healthy diet.

\section{REFERENCES}

AACC (2010).Approved methods of Analysis $11^{\text {th }}$ edition, Methods 10-15D, and 44-15.available online. $A A C C$ International: St-, Plau. MN.

Abdel- Gaber, A. M.; Abd-El-Nabey, B. A.; Sidahaed, I. M. ; El-Zayady, A. M. and Saadawy. M. (2006). Inhibitive action of some plant extracts on the corrosion of steel in acidic media. Corrosion Science Journal. 48 (9):2765-2779.

Abdel-Moemin, A. R. (2016).Effect of Roselle calyces extract on the chemical and sensory properties of functional cupcakes. Journal of Food Science and Human Wellness., 5(4): 230-237.

Abouarab -Azza A.; Abusalem -Ferial, M. and Abouarab -Esmat A. (2011). Physico- chemical properties of natural pigments (Anthocyanin) extracted from Roselle calyces (Hibiscus subdariffa). Journal of American Science, 7(7): 445-456.

Afify-Haiat, M. N. (2012). Biochemical studies on some industrial waste .Ph.D. Thesis, Faculty of Agriculture, and Cairo University, Egypt.

Ahmed, Z. S. and Abozed, S. S. (2015). Functional and antioxidant properties of novel snack crackers incorporated with Hibiscus sabdariffa byproduct. Journal of Advanced Research, 6(1): 79-87.

Alicke, M.; Boakye-Appiah, J. K.; Abdul-Jalil, I.; Henze, A.; van der Giet, M.; Schulze, M. B. and Danquah, I. (2017). Adolescent health in 
rural Ghana: A cross-sectional study on the cooccurrence of infectious diseases, malnutrition and cardio-metabolic risk factors. Journal of Public Library of Science, One, 12(7): e0180436.

Allen, J. C. and Hamilton, R. J. (1983). Rancidity in Food. Applied Science Publishers. New York. pp.85 and 173.

Al-Rifai, R., Nakamura, K. and Seino, K. (2016). Decline in the prevalence of anaemia among children of pre-school age after implementation of wheat flour fortification with multiple micronutrients in Jordan. Public Health Nutrition, 19(8): 1486-1497.

Alsmeyr, R. H.; Cunhingham A. E. and Happich, M. L. (1974). Equation predict PER from amino acid analysis. Journal of Food Technology, 28 (7):34-38.

Amin, T.; Naik, H. R.; Hussain, S. Z.; Jabeen, A. and Thakur, M. (2018). In-vitro antioxidant and antibacterial activities of pumpkin, quince, muskmelon and bottle gourd seeds. Journal of Food Measurement and Characterization, 12(1): 182-190.

Anel, T. C.; Thokchom, R.; Subapriya, M. S.; Thokchom, J. and Singh, S. S. (2016). Hibiscus sabdariffa-A natural micro nutrient source. International Journal of Advanced Research, 3(4): 243-248.

AOAC (2012). Association of Official Analytical Chemists. Official Methods of Analysis, $19^{\text {th }}$ (ed). MARYLAND, USA.

Arpita, M.; Kabita, B. and Kumar, D. A. (2017). Review on Amazing Benefits of Roselle (Hibiscus sabdariffa L.) and Their Uses. World Journal of Pharmacy and Pharmaceutical Sciences, 6 (7): 217-227.

Bala, A.; Gul, K. and Riar, C.S. (2015). Functional and sensory properties of cookies prepared from wheat flour supplemented with cassava and water chestnut flours. Journal of Cogent Food and Agriculture, 1:1-7.

Barbieri, R. and Casiraghi, E. M. (1983): Production of a food grade flour from defatted corn germ meal. International Journal Food Science Technology, 18(1): 35-41.

Bates, K.; Gjonça, A. and Leone, T. (2017). Double burden or double counting of child malnutrition? The methodological and theoretical implications of stunting overweight in low and middle income countries. Journal of Epidemiology Community Health, 71(8):779785.

Batifoulier, F.; Verny, M. A.;Besson, C.; Demigne, C. and Remesy, C. (2005). Determination of thiamine and its phosphate esters in rat tissues analyzed as thiochromes on a RP-amide C16 column. Journal of Chromatography B, 816(1): 67-72.

Beard, J. L. (2001). Iron biology in immune function, muscle metabolism and neuronal functioning. The Journal of nutrition, 131(2): 568S-580S.

Bendich, A. (1989). Carotenoids and the immune response. Journal Nutrition, 119 (1): 112-115.

Bolandi, F.; Shahidi, N.; Sedaghat, R.; Fand, H. and Mousavi-Nik, H. (2008). Shelf-life determination of saffron stigma water activity and temperature studies. World Applied Sciences Journal 5: 132-136.

Boye, J.; Zare, F and Pletch, A. (2010). Pulse proteins: processing, characterization, functional properties and applications in food and feed. Journal of Food Research International, 43(2): 414-431.

Branca, F.; Piwoz, E.; Schultink, W. and Sullivan, L. M. (2015). Nutrition and health in women, children, and adolescent girls. British Medical Journal, 351, h 4173.

Brigide, P.; Canniatt-Brazaca, S. G. and Silva, M. O. (2014). Nutritional characteristics of biofortified common beans. Journal of Food Science and Technology, 34(3):493-500.

Câmara, C. R.; Urrea, C. A and Schlegel, V. (2013). Pinto beans (Phaseolus vulgaris L.) as a functional food: Implications on human health. Agriculture, 3(1):90-111.

Chardigny, J. M. and Walrand, S. (2016).Plant protein for food: opportunities and bottlenecks. Oil seeds and fats, Crops and Lipids, 23(4):D404.

Chevallier, S.; Colonna, P.; Della Valle, G. and Lourdin, D. (2000). Contribution of major ingredients during baking of biscuit dough systems. Journal of Cereal Science, 31(3): 241252.

Chirife, J.; del Pilar Buera, M. and Labuza, T. P. (1996). Water activity, water glass dynamics, and the control of microbiological growth in foods. Critical Reviews in Food Science and Nutrition, 36(5): 465-513.

Cid-Ortega, S. and Guerrero-Beltrán, J. Á. (2014). Roselle calyx's particle size effect on the physicochemical and phytochemicals characteristics. Journal of Food Research, 3(5):83-94.

Da-Costa-Rocha, I.; Bonnlaender, B.; Sievers, H.; Pischel, I. and Heinrich, M. (2014). Hibiscus sabdariffa L. A phytochemical and pharmacological review. Journal of Food Chemistry, 165:424-443.

Day, L. (2013). Proteins from land plants-potential resources for human nutrition and food security. Trends Journal of Food Science and Technology, 32(1): 25-42.

De Carvalho, L. M. J.; Gomes, P. B.; de Oliveira Godoy, R. L.; Pacheco, S.; do Monte, P. H. F.; de Carvalho, J. L. V. and Ramos, S. R. R. (2012). Total carotenoid content, $\alpha$-carotene and $\beta$-carotene, of landrace pumpkins (Cucurbita moschata Duch): A preliminary study. Journal of Food Research International, 47(2): 337-340. 
Dhiman, A. K.; Sharma, K. D. and Attri, S. 2009. Functional constituents and processing of pumpkin: A review. Journal of Food Science and Technology-Mysore, 46: 411-417.

Egyptian Organization for standardization and quality control (2003). Egyptian standard of biscuit No (416).Arab Republic of Egypt, Cairo.

Eissa, H. A.; Hussein, A. S. and Mostafa, B. E. (2007). Rheological properties and quality evaluation on Egyptian balady bread and biscuits supplemented with flours of un-germinated and germinated legume seeds or mushroom. Polish Journal of Food and Nutrition Sciences, 57(4): 487-496.

Elahi, H. H. (1999). Use of emulsifiers on the production of biscuits from composite flour. Pakistan Journal of Food Science, 1(9): 10-14.

El-Nagar, M. I. S. (2005): Effect of adding cereal germs on quality properties and nutritional value of biscuits and cakes. Ph.D. Thesis, Faculty of Agriculture, Cairo University, Egypt.

El-Syiad, S. I. and Hassan, M. A. M. (2014).Quality of White Bean Seeds (Phaseolus vulgaris L.) As Affected by Different Treatments. World Journal of Dairy and Food Sciences, 9 (1): 2028.

FAO (1988). (Hibiscus sabdariffa) in Traditional Food Plant. FAO food and nutrition paper. Food and Agriculture Organization .Rome, Italy, 7(42):328 - 332 .

FAO/WHO. (1974). Hand book on human nutritional requirements. Published by FAO, 53-57, 62-63. Rome.

FAO/WHO. (1991). Protein Quality Evaluation. Reports of a joint FAO/WHO expert Consultation, Food and Agriculture Organization of the United Nations, FAO, Rome.

FAO-STAT (2012). Database of food and agriculture organization, Rome, Italy, Viewed from (http://faostat.fao.org). Assessed 12.01.13.

Faustino, J. F.; Ribeiro-Silva, A.; Dalto, R. F.; Souza, M. M. D.; Furtado, J. M. F.; Rocha, G. D. M. and Rocha, E. M. (2016). Vitamin A and the eye: An old tale for modern times. Arquivos brasileiros de of talmologia, 79 (1):56-61.

Fraser, J. R. and Holmes, D. C. (1959). Proximate analysis of wheat flour carbohydrates. IV.Analysis of whole meal flour and some of its fractions. Journal of the Science of Food and Agriculture, 10(9): 506-512.

Gebremedin, B. D. and Asfaw, B. T. (2017). Effects of Inter and Intra Row Spacing on Growth, Yield and Yield Components of Roselle (Hibiscus Sabdariffa L.) at Wondo Genet, Southern Ethiopia. International Journal of Advanced Biological and Biomedical Research, 6(1): 391-398

Gelli, A. and Daryanani, R. (2013). Are school feeding programmers in low-income settings sustainable? Insights on the costs of school feeding compared to investments in primary education. Journal Food and Nutrition Bulletin, 34 (3): 310-317.

Getahun, Z.; Urga, K.; Ganebo, T. and Nigatu, A. (2017).Review of the status of malnutrition and trends in Ethiopia. The Ethiopian Journal of Health Development, 15(2): 55-74).

Giami, S. Y. and Bekebain, D. A. (1992). Proximate composition and functional properties of raw and processed full-fat fluted pumpkin (Telfairia occidentalis) seed flour. Journal of the Science of Food and Agriculture, 59(3): 321-325

Gomaa-Maha. M. (2012). Chemical and technological studies on some foods: chemical, technological and biological studies on pumpkin fruit. Ph.D. Thesis. Faculty of Agriculture, Kafrelshikh University, Egypt.

Goulder, P. J.; Lewin, S. R. and Leitman, E. M. (2016). Paediatric HIV infection: the potential for cure. Nature Reviews Immunology, 16 (4): 259-271.

Gupta, H.O. and Eggum, B. O. (1998). Processing of maize germ oil cake into edible food grade meal and evaluation of its protein quality. Journal Plant Food Human Nutrition, 52(1): 18.

Hargrove, K.L. (1994). Processing and utilization of rice bran in the United States, In: Marshall, W. E. and Wadsworth, J.I. (Eds.), Rice science and technology, New York: Marcel Dekker: 381-404.

Harrigan, W. F. and Mc Cance, E. M. (1978). Laboratory method for Food and Dairy Microbiology. Academic Press, 18(3):226-227.

Hoojjat, P. and Zabik, M. E. (1984). Sugar-snap cookies prepared with wheat-navy bean-sesame seed flour blends. Journal of Cereal Chemistry, 61(1): 41-44.

Hotz, C. and Brown, K. H. (2004). Assessment of the risk of zinc deficiency in populations and options for its control. International nutrition foundation: for The United Nations University. Food and Nutrition Bulletin, 25 (1):594-5202.

Hu, F. B.; Stampfer, M. J.; Manson, J. E.; Rimm, E.; Colditz, G. A.; Rosner, B. A. and Willett, W. C. (1997). Dietary fat intake and the risk of coronary heart disease in women. New England Journal of Medicine, 337(21): 14911499.

Hu, F. B.; Stampfer, M. J.; Manson, J. E.; Ascherio, A.; Colditz, G. A.; Speizer, F. E. and Willett, W. C. (1999). Dietary saturated fats and their food sources in relation to the risk of coronary heart disease in women. The American Journal of Clinical Nutrition, 70(6): 1001-1008.

Hussein, A. M. S.; El-Azeem, A. A.; Hegazy, A. M. and Ragab, G. H. (2013). Physiochemical, sensory and nutritional properties of corn-fenugreek flour composite biscuits. Journal of Applied Sciences Research, 6(9): 3708-3717.

Hwalla, N.; Al Dhaheri, A. S.; Radwan, H.; Alfawaz, H. A.; Fouda, M. A., Al-Daghri, N. M. and Blumberg, J. B. (2017). The prevalence of 
micronutrient deficiencies and inadequacies in the Middle East and approaches to interventions. Nutrients, 9(3):229.

IUPAC (2000). Standard Methods for the analysis of oils, Fats and Derivatives, 7thet. Published by International Union of pure Applied Chemistry, afford, Great Britain.

Jansen van Rijssen, F. W.; Morris, E. J. and Eloff, J. N. (2013). Food safety: importance of composition for assessing genetically modified cassava (Manihot esculenta Crantz). Journal of Agricultural and Food Chemistry, 61(35): 8333-8339.

Kebebu, A.; Whiting, S. J.; Dahl, W. J. and Henry, C. J. (2013). Formulation of a complementary food fortified with broad beans (Vicia faba) in Southern Ethiopia. African Journal of Food Agriculture Nutrition and Development, 13(3): 7789-7803.

Khalid, H.; Abdalla, W. E.; Abdelgadir, H.; Opatz, T. and Efferth, T. (2012). Gems from traditional north-African medicine: medicinal and aromatic plants from Sudan. Journal of Natural Products and Bioprospecting, 2(3): 92-103.

Khalil, E.; Esoh, R.; Rababah, T.; Almajwal, A. M. and Alu, M. H. (2012). Minerals, proximate composition and their correlations of medicinal plants from Jordan. Journal of Medicinal Plants Research, 6(47): 5757-5762.

Kulaitiene, J.; Danilcenko, H.; Jariene, E.; Jukneviciene, E. and Jukneviciene, E. (2014). Pumpkin fruit flour as a source for food enrichment in dietary fiber. Journal of Notulae Botanicae Horti Agrobotanici Cluj-Napoca, 42(1):19-23

Kumar, R.; Xavier, K. M.; Lekshmi, M.; Balange, A. and Gudipati, V. (2018). Fortification of extruded snacks with chitosan: Effects on techno functional and sensory quality. Carbohydrate Polymer, 194: 267-273.

Kwon, Y. I., Apostolidis, E., Kim, Y. C. and Shetty, K. 2007. Health benefits of traditional corn, beans, and pumpkin: In vitro studies for hyperglycemia and hypertension management. Journal of Medicinal Food, 10 (2): 266-275.

Law, B. M.; Waye, M. M. and So, W. K. (2017). Hypotheses on the Potential of Rice Bran Intake to Prevent Gastrointestinal Cancer through the Modulation of Oxidative Stress. International Journal of Molecular Sciences, 18(7):1-20.

Lee, C. and Beuchat, L. R. (1991) Functional and Sensory Properties of Muffins and Cookies Containing Dried Fermented Peanut Milk. Journal of Lebensmittel-Wissenschaft and Technologie, 24:528-534.

Lee, F.A. (1983). Effect of processing and drying treatment on quality of pumpkin powder. Food Journal, 33:68-76.

Li, T. S. C. (2008). Vegetables and Fruits; Nutritional and therapeutic values. CRC Press, Florida, USA.

Ling, W. H.; Wang, L. L. and Ma, J. (2002): Supplementation of the black rice outer layer fraction to rabbits decreases atherosclerotic plaque formation and increases antioxidant status. Nutrition Journal, 132 (1): 20-26.

Madsen, T.G. (2008). Amino acid contents inrice bran. Asian Feed, (August -September): 27-29.

Manley, D. (Ed.). (2011). Manley's technology of biscuits, crackers and cookies. Elsevier.

Manley, D. and Clark, H. (2011).Biscuit packaging and storage. In Manley's Technology of Biscuits, Crackers and Cookies (Fourth Edition) (pp. 547-563).

Manohar, R. S. and Rao, P. H. (1997). Effect of mixing period and additives on the rheological characteristics of dough and quality of biscuits. Journal of Cereal Science, 25(2): $197-$ 206.

Mc Neely, C. and Blanchard, J. (2010). A guide to healthy adolescent development. Baltimore: center for adolescent health at johns hopkins bloomberg school of public health. Retrieved from http://www.jhsph.edu/research/centersand-institutes/center-for-adolescent-health/.

McGuire, R. G. (1992).Reporting of objective color measurements. Hort. Science, 27(12): 12541255.

Mgaya, K. B.; Remberg, S. F.; Chove, B. E. And Wicklund, T. (2014).Physic-chemical, mineral composition and antioxidant properties of Roselle (Hibiscus sabdariffa L.) extract blended with tropical fruit juices. African Journal of Food, Agriculture, Nutrition and Development, 14(3):8963-8978.

Mishra1, N. and Chandra, R. (2012). Development of functional biscuit from soy flour and rice bran. International Journal of Agricultural and Food Science, 2(1): 14-20.

Mitchel, H. H. and Block, J. (1946). The correlation of amino acid composition of protein with their nutritive value. Nutrition Abstracts and Reviews, 16(2):249.

Mohamed, B. B.; Sulaiman, A. A. and Dahab, A. A. (2012).Roselle (Hibiscus sabdariffa L.) in Sudan, cultivation and their uses. Journal of Bulletin of Environment, Pharmacology and Life Sciences, 1(6): 48-54.

Mohammed, A. A.; Babiker, E. M.; Khalid, A. G.; Mohammed, N. A. and Khadir, E. K. (2016). Nutritional evaluation and sensory characteristics of biscuits flour supplemented with difference levels of whey protein concentrates, Journal of Food Processing and Technology, 7(1): 545 ref.21.

Morrison, M. (1996). Sharing food at home and school: perspectives on commensality. The Sociological Review, 44(4): 648-674.

National Academy of Sciences. (2004). Dietary reference Intakes (DRIs) Estimated average Requirements Food and Nutrition Board, Institute of Medicine, National Academies as reports by accessed via http:// www.nap.edu.

Naves, M. M. V. ; Castro, M. V. L. D.; Mendonça, A. L. D. ; Santos, G. G. and Silva, M. S. (2011). Corn germ with pericarp in relation to whole 
corn: nutrient contents, food and protein efficiency, and protein digestibility-corrected amino acid score. Journal of Food Science and Technology, 31(1): 264-269.

No, P. B. (2015). Healthy meals in schools: Policy innovations linking agriculture. Food Systems and Nutrition, (3):1-16.

Ntatsi, G. ; Gutiérrez-Cortines, M. E. ; Karapanos, I. ; Barros, A. ; Weiss, J.; Balliu, A. and Savvas, D. (2018). The quality of leguminous vegetables as influenced by pre-harvest factors. Journal of Scientia Horticulturae, 232: 191205.

Nustang, J. and Story, M. (2005). Guidelines for adolescent nutrition services. Minneapolis, $\mathrm{MN}$ : Center for Leadership. Education and Training in Maternal and Child Nutrition, Division of Epidemiology and Community Health, School of Public Health, University of Minnesota, 1-8 .

Ogundele, O.; Awolu, O. O.; Badejo, A. A.; Nwachukwu, I. D. and Fagbemi, T. N. (2016).Development of functional beverages from blends of Hibiscus sabdariffa extract and selected fruit juices for optimal antioxidant properties. Journal of Food Science and Nutrition, 4(5): 679-685.

Osorio-Díaz, P.; Bello-Pérez, L. A.; Sáyago-Ayerdi, S. G.; Benítez-Reyes, M. D. P.; Tovar, J. and Paredes-López, O. (2003). Effect of processing and storage time on in vitro digestibility and resistant starch content of two bean (Phaseolus vulgaris L) varieties. Journal Science of Food and Agriculture, 83(12):1283-1288.

Pan, M. L.; Chen, L. R.; Tsao, H. M. and Chen, K. H. (2017). Iron Deficiency Anemia as a Risk Factor for Osteoporosis in Taiwan: A Nationwide Population-Based Study. Nutrients, 9(6):616.

Pelletier, D. L. and Frongillo, E. A. (2003). Changes in child survival are strongly associated with changes in malnutrition in developing countries. The Journal of Nutrition, 133(1):107-119.

Pettifor, J. M.; Fischer, P. R. and Thacher, T. D. (2010). Dietary calcium deficiency and rickets. In Vitamin D. Humana Press. Indian Journal Medical Research, 128:651-667.

Phongthai, S.; Homthawornchoo, W. and Rawdkuen, S. (2017). Preparation, properties and application of rice bran protein: A review. International Journal of Food Research, 24(1): 25-34.

Plozza T.; Trenerry V.C. and Caridi D. (2012). The stimultaneous determination of vitamins $\mathrm{A}, \mathrm{E}$ and $\beta$-carotene in bovine milk by high performance liquid chromatography-ion trap mass spectrometry (HPLC-MSn). Journal of Food Chemistry, 134 (1):559-563.

Priecina, L. and Karklina, D. (2014).Natural Antioxidant Changes in Fresh and Dried Spices and Vegetables, World Academy of Science, Engineering and Technology International
Journal of Nutrition and Food Engineering, 8 (5):492-496.

Purlis, E. (2010). Browning development in bakery products-A review. Journal of Food Engineering, 99(3): 239-249.

Raghav, P. K.; Agarwal, N. and Sharma, A. (2016). Emerging health benefits of rice, International Journal of Multidisciplinary Research and Modern Education, 2 (1): 367-382.

Raghunatha Rao, D.; Vijayapushpam, T.; Subba Ra, G.M.; Antony, G.M. and Sarma, K. V. R. (2007): Dietary habits and effect of two different educational tools on nutrition knowledge of school-going adolescent girls in Hyderabad, India. Eur. Journal of Clinical Nutrition, 61 (9):1081-1085.

Ribeiro, E. D. S.; Centeno, D. D. C.; FigueiredoRibeiro, R. D. C.; Fernandes, K. V. S.; XavierFilho, J. and Oliveira, A. E. A. (2011). Free cyclitol, soluble carbohydrate and protein contents in Vigna unguiculata and Phaseolus vulgaris bean sprouts. Journal of Agricultural and Food Chemistry, 59(8): 4273-4278.

Rohrer, C. A. and Siebenmorgen, T. J. (2004). Nutraceutical concentrations within the bran of various rice kernel thickness fractions. Journal of Biosystems engineering, 88(4): 453-460.

Sabanis, D. and Tzia, C. (2009). Effect of rice, corn and soy flour addition on characteristics of bread produced from different wheat cultivars. Journal of Food Bioprocess Technology, 2 (1):68-79.

Saini, P.; Yadav, N.; Kaur, D; K Gupta, V.; Kaundal, B.; Mishra, P. and Kumar, R. (2017).Physicochemical, Functional and Biscuit Making Properties of Wheat Flour and Potato Flour Blends. Journal of Current Nutrition and Food Science, 13(3): 192-197.

Salunkhe, D. K., Chavan, J. K., Adsule, R. N. and Kadam, S. S. (1992): Rice, In: World oilseeds:Chemistry, technology and utilization a Nostr and Reinhold, New York: 424-448.

San José, F. J.; Collado-Fernández, M. ; López, R. (2018). Sensory evaluation of biscuits enriched with artichoke fiber-rich powders (Cynara scolymus L.). Journal of Food Science and Nutrition, 6(1): 160-167.

SAS. (1985). SAS user's guide: Statistics. Version 5 ed. SAS Institute, Inc., Cary, N.C.

Sawyer, S. M., Afifi, R. A., Bearinger, L. H., Blakemore, S. J., Dick, B., Ezeh, A. C. and Patton, G. C. (2012). Adolescence: a foundation for future health. The Lancet, 379(9826): 1630-1640.

See, E. F.; Wan Nadiah, W. A. and Noor Aziah, A. A. (2007): Physico-Chemical and Sensory Evaluation of Breads Supplemented with Pumpkin Flour. ASEAN Food Journal, 14 (2): 123-130.

Serrem, C. A.; de Kock, H. L. And Taylor, J. (2011). Nutritional quality, sensory quality and consumer acceptability of sorghum and bread wheat biscuits fortified with defatted soy flour. 
International Journal of Food Science and Technology, 46(1): 74-83.

Shahidi, F.; Sedaghat, N.; Farhoush, R. and MousaviNik, H. (2008). Shelf-life determination of saffron stigma: Water activity and temperature studies. Journal of World Applied Sciences, 5 (2): 132-136.

Shahine-Fatma, I.; Amer-Thanaa, A. M. and Mona, M. M. Dowidar (2013). Preparation and evaluation healthy filling pie by using cheese and some vegetables. In: AlAzhar Center for Conference, Naser City, Egypt. Journal of Agriculture Research, 91 (1):43-66.

Siddiq, M.; Kelkar, S.; Harte, J. B.; Dolan, K. D. and Nyombaire, G. (2013). Functional properties of flour from low-temperature extruded navy and pinto beans (Phaseolus vulgaris L.). LWTJournal of Food Science and Technology, 50(1): 215-219.

Singh, B.; Singh; J. P.; Shevkani, K.; Singh, N. and Kaur, A. (2017). Bioactive constituents in pulses and their health benefits. Journal of Food Science and Technology, 54(4): 858-870.

Soetan, K. O.; Olaiya, C. O. and Oyewole, O. E. (2010). The importance of mineral elements for humans, domestic animals and plants-A review. African Journal of Food Science, 4(5): 200-222.

Stang, J. and Story, M. (2005).Guidelines for Adolescent Nutrition Services. Minneapolis, $\mathrm{MN}$ : Center for Leadership, Education and Training in Maternal and Child Nutrition, Division of Epidemiology and Community Health, School of Public Health, University of Minnesota: 1-8.

Stone, H. (2012). Sensory evaluation practices. Academic press, $4^{\text {th }}$ edition.

Suchdev, P. S. (2017). What Pediatricians Can Do to Address Malnutrition Globally and at Home Pediatrics, e20161666.

Tan, B. L. and Norhaizan, M. E. (2017). Scientific evidence of rice by-products for cancer prevention: chemopreventive properties of waste products from rice milling on carcinogenesis in vitro and in vivo. Bio Med Research International, Volume 2017, Article ID 9017902:1-18.

Toomer, O. T. (2017).Nutritional chemistry of the peanut (Arachis hypogaea). Critical reviews in food science and nutrition, 1-12.

Trinidad, T. P.; Mallillin, A. C.; Loyola, A. S.; Sagum, R. S. and Encabo, R. R. (2010). The potential health benefits of legumes as a good source of dietary fiber. British Journal of Nutrition, 103 (4): 569-574.

UNICEF. (2015).Progress for children: a report card on adolescents, (10):1:52, 2012. UNICEF. Progress for Children: Beyond Averages Learning from the MDGs, 11:1-68.

Wade, P. (1988). Biscuits, cookies, and crackers. Elsevier applied science, 1:102-114.

Wander, K.; Shell-Duncan, B. and Brindle, E. (2017). Lower incidence of respiratory infections among iron-deficient children in Kilimanjaro, Tanzania. Evolution, Medicine and Public Health, 2017(1): 109-119.

Wertich, L. (2013). Healthy Habits for Life. group.

WHO. (1994). Guideline value for food and drinking water, World Health Organization Geneva: 3-4.

Xia, N.; Wang, J.; Yang, X.; Yin, S.; Qi, J.; Hu, L. and Zhou, X. (2012). Preparation and Characterization of Protein from HeatStabilized Rice Bran Using Hydrothermal Cooking Combined with Amylase Pretreatment. Journal of Food Engineering, 110(1): 95-101.

Yanagisawa, H. (2004).Zinc deficiency and clinical practice. Japan Medical Association Journal, 47(8), 359-364.

Younas, A.; Bhatti, M. S.; Ahmed, A. and Randhawa, M. A. (2011). Effect of rice bran supplementation on cookie baking quality. Pakistan Journal of Agricultural Sciences, 48(2): 129-134. 


\section{إعداد وتقيم بسكويث مدعم ببعض الإضافات الطبيعية لتغذية الأطفال والمراهقين

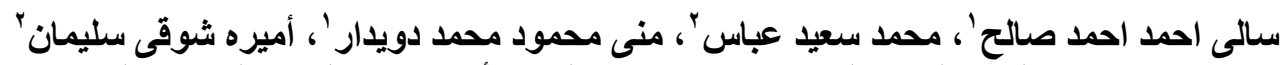

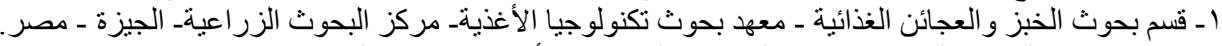 r ـ قسم الموارد الطبيعية ـ معهد البحوث و الدر اسات الأفريقية ـجامعة القاهرةـ مصرك.}

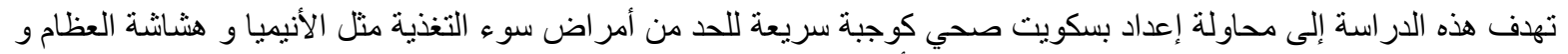

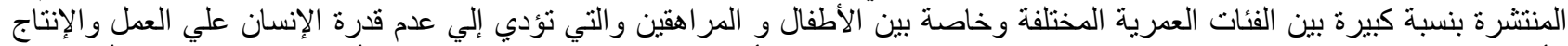

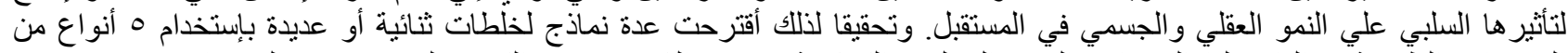

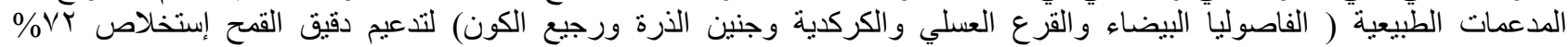

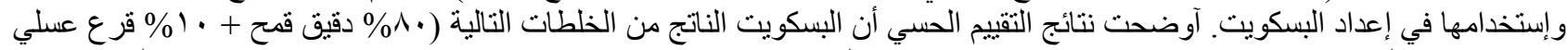

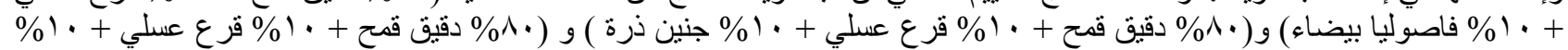

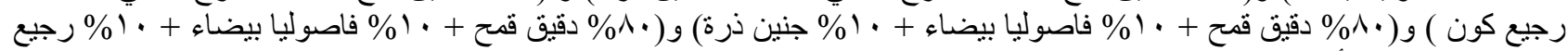

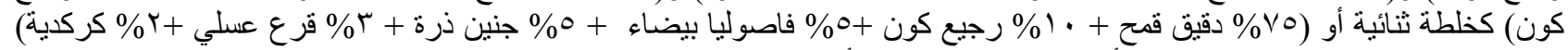

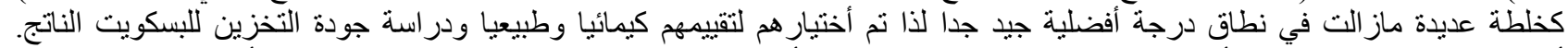

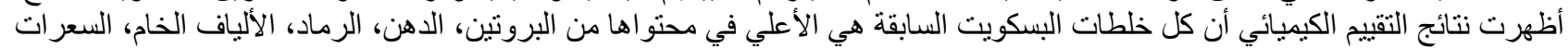

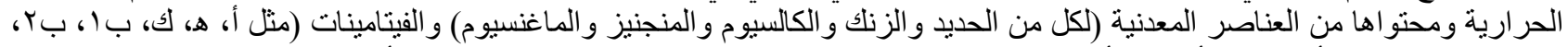

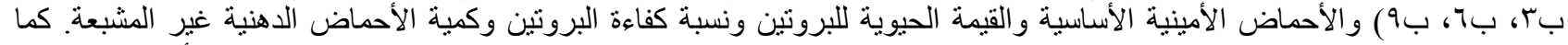

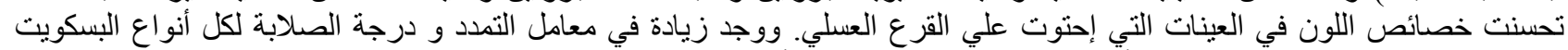

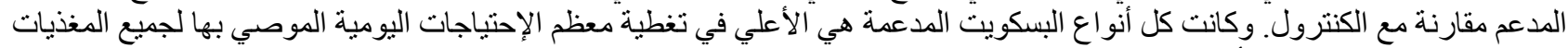

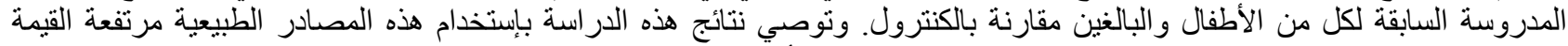

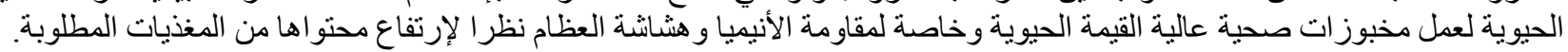

